\title{
Denying Deference: Civil Rights and Judicial Resistance to Administrative Constitutionalism
}

\author{
Bertrall L. Ross $I^{\dagger}$
}

\section{INTRODUCTION}

What determines the level of deference the Supreme Court gives to agency interpretations of statutes? For over a half century, scholars have tried to make sense of the Supreme Court's apparently inconsistent application of deference doctrines. The leading scholarly view has been that the level of judicial deference depends on the form the agency interpretation takes. According to this account, when agency interpretations are in a legislative rule adopted through notice-and-comment procedures and have the "force of law," the Court applies a heightened deference standard. ${ }^{1}$ But when agency interpretations are in interpretive or other non-legislative rules adopted through less formalized procedure and lack the "force of law," the Court usually gives only minimal deference. ${ }^{2}$ I term

$\dagger$ Assistant Professor of Law, University of California-Berkeley School of Law. The author would like to thank Christopher Edley, Jamal Greene, Maggie Lemos, Gillian Metzger, Anne Joseph O'Connell, and participants at the University of Chicago Legal Forum symposium on the Civil Rights Act at 50 years and the Duke Law School Culp Colloquium for their helpful comments and generous feedback. I owe my greatest appreciation to Joy Milligan for her ideas and inspiration along with careful reads of several drafts.

1 Section 553 of the Administrative Procedure Act of 1946 gave agencies the authority, and established the procedural framework that agencies were required to follow, to issue legislative rules. See 5 USC $\$ 553$. Legislative rules are also referred to as substantive rules and, according to the Attorney General's Manual on the Administrative Procedure Act, such rules are "issued by an agency pursuant to statutory authority[,] . . implement the statute, [and] ... have the force and effect of law." United States Department of Justice, Attorney General's Manual on the Administrative Procedure Act, 30 n 3 (1947). See also Note, Rule Making: Some Definitions Under the Federal Administrative Procedure Act, 35 Georgetown L J 491, 496-97 (1947) ("A substantive rule then might well be described as an agency statement, with force and effect of law, implementing by 'filling in the details' of a statute which by its terms refers to administrative action as necessary to complete the rule of conduct sought to be prescribed.").

2 Section 553 of the Administrative Procedure Act of 1946 exempts "interpretative 
the framework the "deference dichotomy" based on its sharp distinction between legislative and interpretive rules. On some accounts, the Court has followed the deference dichotomy since the birth of modern administrative law, ${ }^{3}$ though it did not formally announce its adoption of the dichotomy until two cases in 2000 and 2001-Christensen v Harris County ${ }^{4}$ and United States v Mead. ${ }^{5}$

Though it is the leading explanation of judicial deference choices, the deference dichotomy fails to account for much of the Court's practice both before and after Christensen-Mead. In earlier decades, the Court's actual deference patterns did not

rules, general statements of policy, or rules of agency organization, procedure, or practice" from the formalized requirement of notice-and-comment rulemaking. 5 USC $\S 553(\mathrm{~b})(3)(\mathrm{A})$. According to the Attorney General's Manual on the Administrative Procedure Act, interpretative rules are "rules or statements issued by an agency to advise the public of the agency's construction of the statute and rules which it administers." See United States Department of Justice, Attorney General's Manual on the Administrative Procedure Act at $30 \mathrm{n} 3$ (cited in note 1). In some cases, the distinction between legislative rules and non-legislative rules has been much more difficult to demarcate in practice. See Kristin E. Hickman, Unpacking the Force of Law, 66 Vand L Rev 465, 473 (2013) (noting that a small subset of agency rules fall somewhere in the middle between legislative and interpretive rules). The minimal deference standard was first articulated in Skidmore v Swift \& Co, in which the Court explained that deference is only owed to agency interpretations to the extent that they have the power to persuade. 323 US 134 (1944); see also Part I.A-B. At times, the Court applied neither heightened deference nor minimal deference frameworks. I group these cases in which the Court applies no deference with those in which it applies minimal deference and argue that in these cases, the Court, for the most part, exercises independent judgment over the meaning of the statute. Since disputes about the nature of the agency action have not been central to the cases examined in this article, I do not engage the extensive debate about how to distinguish the two forms of rules. For sources discussing that distinction, see, for example, David L. Franklin, Legislative Rules, Nonlegislative Rules, and the Perils of the Short Cut, 120 Yale L J 276, 286-88 (2010); Jacob Gersen, Legislative Rules Revisited, 74 U Chi L Rev 1705, 1708-13 (2007); John F. Manning, Nonlegislative Rules, 72 Geo Wash L Rev 893, 917-923 (2004); William Funk, A Primer on Nonlegislative Rules, 53 Admin L Rev 1321, 1324-25 (2001); Robert A. Anthony, Interpretive Rules, Policy Statements, Guidances, Manuals, and the LikeShould Federal Agencies Use Them to Bind the Public?, 41 Duke L J 1311, 1321-30 (1992); Michael Asimow, Nonlegislative Rulemaking and Regulatory Reform, 1985 Duke L J 381, 383-84; David R. Woodward and Ronald M. Levin, In Defense of Deference: Judicial Review of Agency Action, 31 Admin L Rev 329, 341-42 (1979); Arthur Earl Bonfield, Some Tentative Thoughts on Public Participation in the Making of Interpretative Rules and General Statements of Policy Under the APA, 23 Admin L Rev 101, 110-12 (1971); Robert Kramer, The Place and Function of Judicial Review in the Administrative Process, 28 Fordham L Rev 1, $85-93$ (1959); Kenneth Culp Davis, Administrative Rules - Interpretative, Legislative, and Retroactive, 57 Yale L J 919, 92834 (1948)

3 See Part I.A.

4529 US $576(2000)$.

5533 US $218(2001)$. 
consistently follow either the deference dichotomy or the Court's own precedents. At times, the Court applied deferential review to mere interpretive rules, and at other times it refused to apply such review to legislative rules. ${ }^{6}$ In the years after ChristensenMead, the Court has more closely adhered to the deference dichotomy, but important deviations remain. ${ }^{7}$ What explains the Court's pattern then, if not the widely accepted deference dichotomy or the Court's own precedents?

The primary alternative explanation, animated by a legal realist account of judicial behavior, suggests that deference choices are driven by judicial preferences for particular outcomes. Scholars examining deference choices at a macro-level have attempted to empirically test whether ideology drives judicial deference choices in a broad number of administrative law cases. However, they have come to contradictory conclusions. ${ }^{8}$ Even aside from the contradictory findings regarding whether judges' ideology affects deference choices, these studies assume that a particular set of factors drive deference across all substantive fields and agencies. If in fact the factors underlying deference choices vary depending on the field or agency, then those factors might not be susceptible to empirical identification using a macro-level strategy.

Another set of explanations for deference choices focuses on judicial views about the competency of the agency administering the statute and the complexity of the relevant legal regime. These explanations arise from agency-specific studies that examine how courts have treated particular agencies administering particular statutes. ${ }^{9}$ While the agency-specific studies, like their macro-level counterparts, provide important insights into judicial deference choices, the factors they identify may not generalize to other agencies or statutory regimes. Moreover, because of their particularized focus, these agencyspecific accounts cannot address broader themes in judicial application of deference doctrines that extend across agencies

\footnotetext{
6 See Part I.A-B. When I refer to the Court applying heightened or minimal deference, it does not mean that the Court has deferred or not deferred to the particular agency interpretation. It only refers to the Court's determination about whether to use the agency's interpretation as a starting point for statutory meaning or to engage in its own independent judgment about the meaning of the statute. See Part II.C.

7 See Part I.B.

8 See Part I.C.

9 See Part I.C.
} 
and statutes. Such patterns might not be salient when examining judicial deference choices with respect to a particular agency's interpretation but might become clear in patterns of judicial deference choices with respect to multiple agencies' interpretations.

In this Article, I pursue an alternative path toward identifying sources of judicial deference choices, by analyzing patterns of judicial deference toward agency interpretations in an entire substantive area-civil rights. Civil rights is a promising area for analysis because it is in this area that the Court has shown some of its greatest inconsistencies in its application of deference doctrine. Focusing on an entire substantive field also offers an intermediate level of analysis, steering between the macro-level and agency-specific accounts.

Civil rights are embodied in a variety of statutes enforced by a range of agencies. Since the 1960s, Congress has enacted statutes designed to redress discrimination in several different areas of activity, including employment, education, public accommodations, and voting. ${ }^{10}$ In addition, Congress has extended these non-discrimination protections to racial minorities, women, the aged, and the disabled. ${ }^{11}$ Each of these civil rights statutes is administered by agencies, including the Equal Employment Opportunity Commission (EEOC) for the employment provisions of the civil rights statutes, the Department of Justice (DOJ) for the Voting Rights Act (VRA), and the now-defunct Department of Health, Education, and Welfare (HEW) for the education provisions of the Civil Rights Act. ${ }^{12}$ These agencies have employed different forms of agency interpretation, with the EEOC interpreting employment statutes through the use of both legislative and interpretive rules, the DOJ interpreting the voting rights statute through the use of interpretive rules, and HEW interpreting the education statute through the use of legislative and interpretive rules. ${ }^{13}$

10 See, for example, Americans with Disabilities Act of 1990, Pub L No 101-336, 104 Stat 327, codified at 42 USC $\$ 12101$ et seq; Age Discrimination in Employment Act of 1967, Pub L No 90-202, 81 Stat 602, codified at 29 USC $\$ \$ 621-34$; Voting Rights Act of 1965, Pub L No 89-110, 79 Stat 437, codified at 42 USC $\$ \$ 1973-1973 \mathrm{bb}-1$; Civil Rights Act of 1964, Pub L No 88-352, 78 Stat 241, codified as amended in scattered sections of 42 USC.

11 See statutes cited in note 10 .

12 See statutes cited in note 10.

13 See Part II.A. 
In this article, I examine the Court's pattern of deference toward these agencies' interpretations of civil rights statutes over several decades. This field-level approach borrows from the more macro-level analyses of judicial deference in that it looks across multiple agencies and multiple statutes. It therefore provides a more generalizable basis for understanding judicial deference choices than an agency-specific analysis. The fieldlevel approach also borrows from the more micro-level analyses by providing a closer qualitative examination of the particulars of these judicial deference choices. This approach may capture important but nuanced factors relevant to judicial deference choices that a macro-level statistical analysis would miss.

The examination reveals that the available theories only weakly explain the Supreme Court's deference choices in the field of civil rights. According to the deference dichotomy, the Court should give heightened deference to the agencies' legislative rules and minimal to no deference to their interpretive rules. The civil rights case law only loosely follows this pattern. The Court has given heightened deference to some interpretive rules and minimal or no deference to others, while giving minimal or no deference to certain legislative rules and heightened deference to others. The ideology account, which suggests that judicial deference choices should turn on whether the justice agrees ideologically with the agency's interpretation provides, at best, a partial explanation for such choices. While ideology may explain some portion of judicial disagreement about whether to defer, the justices tended more often than not to agree across the ideological spectrum about whether a heightened or minimal deference framework applied. When the justices disagreed about the application of deference frameworks, the alignment of justices did not tend to accord with the predictions of the ideology account. Finally, explanations for judicial deference choices such as the complexity of the legal regime and judicial views about the agency cannot entirely account for judicial deference choices in the civil rights domain. Because these explanations are either statute or agency-specific, they would imply that each of the justices should be consistent in applying deference frameworks to particular statutes and agencies, based on how they view the complexity of the statute or the competency of the agency. But this has not been the case. 
Instead, judicial deference choices in the civil rights domain appear to have been motivated by something that has gone unnoticed in the literature thus far-judicial resistance to "administrative constitutionalism." Gillian Metzger has defined administrative constitutionalism as "the elaboration of new constitutional understandings by administrative actors." 14 Statutory questions about the meaning of "discrimination," what it means to act with a discriminatory purpose or effect, and what classes of individuals are "discrete and insular" implicate ongoing constitutional controversies about the meaning of equal protection and the non-discriminatory right to vote. To the extent that agencies actively resolve these questions through statutory interpretation, they are engaged in administrative constitutionalism. Even if the agencies do not consciously set out to weigh in on constitutional questions, by fleshing out statutes that rest on constitutional values, the agencies are construing the Constitution. These Constitution-based value judgments do not necessarily become embedded into the Constitution itself, but the agencies' constitutional judgments do become a part of our broader constitutional framework and value system represented by the statutes. ${ }^{15}$

A distinct pattern emerges in the cases involving the question of what level of deference to apply to agency interpretations of civil rights statutes. When civil rights agencies have engaged in administrative constitutionalism, the Court has tended to refuse to apply heightened deference to the agency's interpretation of the statute. The Court has refused to apply heightened deference in these cases even when precedent and the governing deference framework suggest that it shouldthus resisting administrative constitutionalism. However, when the civil rights agency interpretations do not implicate active constitutional controversies, the Court has tended to adhere to

\footnotetext{
14 See Gillian E. Metzger, Administrative Constitutionalism, 91 Tex L Rev 1897 , 1900 (2013). See also Sophia Z. Lee, Race, Sex, and Rulemaking: Administrative Constitutionalism and the Workplace, 1960 to the Present, 96 Va L Rev 799, 801 (2010) (defining administrative constitutionalism as "regulatory agencies' interpretation and implementation of constitutional law"); William Eskridge and John Ferejohn, A Republic of Statutes: The New American Constitution 26-27 (Harvard 2010) (describing administrative constitutionalism as the process by which agencies "consider and interpret the ... Constitution").

15 See Eskridge and Ferejohn, A Republic of Statutes at 12-18 (cited in note 14) (describing the process by which small " $\mathrm{c}$ " constitutional norms established in statutes and their interpretations become entrenched into the polity).
} 
the governing deference framework announced in its own decision.

While these cases may seem to involve technicalities of administrative law, the Court's decisions about deference frameworks in fact implicate profound questions about authority over constitutional meaning. When the Court denies heightened deference to administrative constructions of the Constitution, it is asserting control over the meaning of statutes in order to preserve its own power to determine constitutional meaning. The Court seems to be asserting through its resistance that it, not the responsible agency, will play the dominant role in defining the substance of civil rights statutes insofar as they implicate controversial constitutional questions.

In the following, I proceed in two parts. In Part I, I describe how scholars, and more recently the Court itself, have attempted to rationalize the Court's pattern of deference to agencies' statutory interpretations by distinguishing between the deference due legislative and interpretive rules. I note that this rationale does not itself accord with the Court's formal precedents before 2000; further, the Court's actual deference pattern did not entirely track either the deference dichotomy or its formal precedents. I then consider other scholars' attempts to explain the Court's actual deference patterns and argue that they are not entirely satisfying either. In Part II, I focus on the civil rights context and offer an alternative understanding of the Court's inconsistent deference patterns, one centered on judicial resistance to administrative constitutionalism. I provide a theory to account for the Court's resistance and address its implications for the future scope of civil rights statutes.

\section{DefERence Patterns \& Potential Rationales}

Statutes passed by Congress are inevitably ambiguous. The imprecision of human language, the inability to foresee all future circumstances of statutory application, and simple dereliction of legislative responsibility to define terms in the face of disagreement all contribute to this ambiguity. The Constitution does not delegate statutory interpretive responsibility to any particular institution, but the constitutional responsibilities of the judicial and executive branches suggests that they both have an interpretive role. The executive branch's responsibility to "take Care that the Laws be 
faithfully executed" and the judicial branch's responsibility to adjudicate cases and controversies will inevitably require interpretation of ambiguous laws. ${ }^{16}$ Further, agencies also interpret statutes when adjudicating disputes or issuing generally applicable rules.

When courts review agency interpretations of statutes, they must decide what level of deference applies. The Supreme Court in its review of agency interpretations has vacillated between applying heightened deference to some agency interpretations and minimal to no deference to others. Until 2000, the Court did not account for these deference choices, but scholars suggested that they could be explained by a deference dichotomy. According to this dichotomy, the Court applied heightened deference to more formal agency interpretations that have the force of law and lesser deference to informal agency interpretations lacking such binding legal effect. When the Supreme Court ultimately enshrined this dichotomy into case law, some scholars saw it as a mere affirmation of an already established pattern of judicial deference choices. ${ }^{17}$ In the following, I describe the pattern of deference choices and show how it has not fit the deference dichotomy. I then examine alternative scholarly accounts for the pattern of judicial deference choices and argue that they are also unsatisfying.

\section{A. Early Judicial Deference Choices}

In the early nineteenth century, the Court began to address the question of how much deference was owed to agency interpretations of statutes. In the 1827 case of Edwards' Lessee $v$ Darby, ${ }^{18}$ the Court explained that "[i]n the construction of a doubtful and ambiguous law, the contemporaneous construction of those who were called upon to act under the law, and were appointed to carry its provisions into effect, is entitled to very great respect." 19 A half century later in the 1877 case of United

\footnotetext{
16 US Const Art II, § 3; US Const Art III, § 2 .

17 See, for example, Kristin E. Hickman and Matthew D. Krueger, In Search of the Modern Skidmore Standard, 107 Colum L Rev 1235, 1245 (2007) ("[Christensen and Mead] reaffirmed Skidmore as the deference standard for most administrative interpretations.").

1825 US 206 (1827).

19 Id at 210.
} 
States $v$ Moore, ${ }^{20}$ the Court offered a slightly different formulation, announcing, "[t]he construction given to a statute by those charged with the duty of executing it is always entitled to the most respectful consideration, and ought not to be overruled without cogent reasons." ${ }^{21}$ The Court in dozens of subsequent cases over the next seventy-five years cited and followed these and similar articulations of the level of deference owed to agency interpretations. ${ }^{22}$ But the Court did not always defer to agency interpretations in this way.

On many occasions, the Court exercised considerable independent judgment as to the meaning of the statute, giving little to no weight to agency constructions. Most famously, in the 1944 case of Skidmore $v$ Swift and Co, ${ }^{23}$ the Court in its review of an agency order interpreting the Fair Labor Standards Act explained, "the weight of [an agency's] judgment in a particular case will depend upon the thoroughness evident in its consideration, the validity of its reasoning, its consistency with earlier and later pronouncements, and all those factors which give it power to persuade, if lacking power to control." 24 This description of the deference due the agency appeared to be much different than the Court's prior formulations of "great respect" and "most respectful consideration." In fact, insofar as courts only deferred to the extent that the agency's interpretation was persuasive, the Skidmore formulation did not appear to require any more deference than the court would give to a litigant's brief. ${ }^{25}$ The Court in Skidmore did not cite its earlier deference

2095 US 760 (1877).

21 Id at 763 .

22 See, for example, Udall v Tallman, 380 US 1, 16 (1965); United States v Leslie Salt Co, 350 US 383, 396 (1956); Great Northern Railway Co v United States, 315 US 262, 275 (1942); Norwegian Nitrogen Products Co v United States, 288 US 294, 315 (1933); Fawcus Machine Co v United States, 282 US 375, 378 (1931); Logan v Davis, 233 US 613, 627 (1914); Heath v Wallace, 138 US 573, 582 (1891); United States v Johnston, 124 US 236, 253 (1888); Barbour v City of Louisville, 120 US 169, 182 (1887); Brown v United States, 113 US 568, 571 (1885). See also Henry P. Monaghan, Marbury and the Administrative State, 83 Colum L Rev 1, 16 (1983) ("[T]hroughout most of the nineteenth century there was ... only limited judicial control of administrative lawinterpretation.").

23323 US 134 (1944).

24 Id at 140 .

${ }^{25}$ The dominant view of Skidmore deference is that it allows judges to independently determine the meaning of statutes interpreted by agencies. See, for example, J. Lyn Entrikin Goering, Tailoring Deference to Variety with a Wink and a Nod to Chevron: The Roberts Court and the Amorphous Doctrine of Judicial Review of Agency Interpretations of Law, $36 \mathrm{~J}$ Legis 18, 61 (2010) ("[A]ll that Skidmore . . guarantee[s] is 
standards so it is impossible to ascertain its understanding of the relationship between the new and the old. Nor did the Court in Skidmore explain the boundaries of the new deference standard. Did it only apply to the statutory interpretations of low-level administrators like those at issue in the case or did it apply more broadly? Not until 2000 and 2001 did the Court provide reasons for differentiating between the two forms of deference. ${ }^{26}$ In the intervening decades, there was no express explanation for the choice of deference or pattern in case law for when the Court gave deference and when it did not.

Two years after Skidmore, Congress enacted the Administrative Procedure Act (APA) to rationalize agency procedures and judicial review of agency actions. ${ }^{27}$ The APA demarcates two forms of agency action-adjudication and rulemaking - and further subdivides the two forms into formal and informal categories, adopting procedural requirements for each. ${ }^{28}$ The form of agency action most relevant to the deference dichotomy is informal rulemaking, which over time evolved into a principal means for agency action. ${ }^{29}$ The APA requires that agencies issuing rules through informal rulemaking follow a procedure of notice and comment. ${ }^{30}$ Under notice and comment,

that the court will give the agency's interpretation some consideration."); Monaghan, Marbury and the Administrative State, 83 Colum L Rev at 3 (cited in note 22); Clark Byse, Scope of Judicial Review in Informal Rulemaking, 33 Admin L Rev 183, 191 (1981). See also Colin S. Diver, Statutory Interpretation in the Administrative State, 133 U Pa L Rev 549, 553-55 (1985) (describing statutory interpretation in the independent mode). But more recently, two scholars engaging in an empirical examination of Skidmore deference in the lower courts have argued that the deference model is sometimes applied in a way that is quite deferential to the agency interpretation of the statute. See Hickman and Krueger, In Search of the Modern Skidmore Standard, 107 Colum L Rev at 1271-80 (cited in note 17) (differentiating between Skidmore as an independent judgment model and as a model of deference that varies along a sliding scale and finding in the courts of appeals that the latter model dominates). See also Jim Rossi, Respecting Deference: Conceptualizing Skidmore Within the Architecture of Chevron, 42 Wm \& Mary L Rev 1105, 1111 (2001) (identifying three ways to conceptualize Skidmore deference after Mead).

26 See text accompanying notes $4-5$.

27 The Administrative Procedure Act, Pub L No 79-404, 60 Stat 237 (1946), codified at 5 USC $\$ 500$ et seq.

28 See 5 USC $\$ \$ 553-554$.

29 M. Elizabeth Magill, Agency Choice of Policymaking Forum, 71 U Chi L Rev 1383, 1384-85 (2004) (noting the shift from adjudication as the predominant form of agency action in the $1950 \mathrm{~s}$ and $1960 \mathrm{~s}$ to rulemaking in the 1970s); Reuel E. Schiller, Rulemaking's Promise: Administrative Law and Legal Culture in the 1960s and 1970s, 53 Admin L Rev 1139, 1145-51 (2001) (describing the ascendancy of rulemaking in the late $1960 \mathrm{~s}$ and early $1970 \mathrm{~s})$.

305 USC $\$ \S 553(\mathrm{~b})-(\mathrm{c})$. 
agencies must provide members of the public with notice of a proposed rule (principally through publication in the Federal Register) and the opportunity to comment on it through submission of "written data, views, or arguments" to the agency. ${ }^{31}$ Only after accounting for public comments can the agency issue the rule. ${ }^{32}$ This innovative method of agency action was designed to enhance the democratic legitimacy of the administrative state by providing for public participation in agency decision-making. ${ }^{33}$ Beginning in the 1970s, agencies increasingly turned to notice-and-comment rulemaking procedures to fill statutory gaps with regulations that had the same legal force and effect as statutes themselves. ${ }^{34}$

The APA differentiates between the agency's authority to issue rules to fill statutory gaps and its authority to interpret statutes. While agencies are required to issue rules through notice-and-comment procedures to fill statutory gaps, the APA exempts "interpretative rules, general statements of policy, or rules of agency organization, procedure, or practice" from the procedural requirement. ${ }^{35}$ According to the Attorney General's Manual on the Administrative Procedure Act, agencies have the authority to issue these non-legislative rules "to advise the public of the agency's construction of the statutes and rules which it administers." 36 Unlike legislative rules, these nonlegislative rules do not have the same binding legal effect as statutes. ${ }^{37}$

315 USC $\$$ 553(b)-(c). See also Cornelius M. Kerwin and Scott R. Furlong, Rulemaking: How Government Agencies Write Law and Make Policy 58-113 (CQ 2d ed 1999) (describing the rulemaking process as it has evolved).

325 USC $\$ 553(\mathrm{c})$.

33 See Kerwin and Furlong, Rulemaking at 158 (cited in note 31) ("Participation contributes more ... legitimacy to the rulemaking process [and] can also enhance the authority of the rule.").

34 Magill, $71 \mathrm{U}$ Chi L Rev at 1384-85 (cited in note 29) (noting the shift from adjudication as the predominant form of agency action in the $1950 \mathrm{~s}$ and $1960 \mathrm{~s}$ to rulemaking in the 1970s); Schiller, 53 Admin L Rev at 1145-51 (cited in note 29) (describing the ascendancy of rulemaking in the late $1960 \mathrm{~s}$ and early $1970 \mathrm{~s}$ ).

355 USC $\$ 553(\mathrm{~b})$.

36 United States Department of Justice, Attorney General's Manual on the Administrative Procedure Act at $30 \mathrm{n} 3$ (cited in note 1).

37 The inherent difficulty with distinguishing statutory gap filling from statutory interpretation and identifying when an agency action has the force of law plagued all future efforts to establish clear distinctions between legislative and interpretive rules. See note 2 (citing articles assessing the difficulty of distinguishing legislative and nonlegislative rules). See also Hickman, 66 Vand L Rev at 475 (cited in note 2) (noting that the Supreme Court has never defined the meaning of "force of law"); Cass R. Sunstein, 
In addition to establishing procedures for the different forms of agency action, the APA also codified the scope of judicial review of agency action. ${ }^{38}$ Under this standard, "the reviewing court shall decide all relevant questions of law, interpret constitutional and statutory provisions, and determine the meaning or applicability of the terms of an agency action." 39 Congress never clearly addressed the question of whether deference was owed to agency interpretations and, if so, what level of deference applied. ${ }^{40}$ But the language of the APA at least suggests Congress intended for courts to exercise independent judgment over the meaning of statutes. ${ }^{41}$ Importantly, in articulating the scope of review, Congress did not distinguish between the different forms of agency actions. Whether the agency issues adjudicative orders or rules, legislative rules or interpretive rules, the same form of judicial review appears to be applicable under the APA. ${ }^{42}$

Nonetheless, different forms of judicial review and deference to agencies quickly emerged after the enactment of the APA. In the period immediately surrounding the debate and adoption of the APA from 1945 to 1947, the Court applied the Skidmore standard in a series of cases involving review of agency interpretations of ambiguous statutes. ${ }^{43}$ Most of these

Chevron Step Zero, 92 Va L Rev 187, 222 (2006) (identifying two possible interpretations of "force of law").

385 USC $\$ 706$.

39 Id. The APA provision goes on to mandate that reviewing courts:

hold unlawful and set aside agency action, findings, and conclusions found to be-(A) arbitrary, capricious, an abuse of discretion, or otherwise not in accordance with law, (B) contrary to constitutional right, power, privilege, or immunity; [and] (C) in excess of statutory jurisdiction, authority, or limitations, or short of statutory right [.]

5 USC $\$ 706(2)$.

40 See, for example, Russell L. Weaver, The Emperor Has No Clothes: Christensen, Mead, and Dual Deference Standards, 54 Admin L Rev 173, 181 (2002) (explaining that Congress has not "instruct[ed] courts when to defer to administrative interpretations").

${ }^{41}$ See, for example, Cass R. Sunstein, Law and Administration after Chevron, 90 Colum L Rev 2071, 2086 (1990) (arguing that the scope of review provisions of the APA "suggest[ed] a firm belief in the need for judicial checks on administration, particularly with respect to the interpretation of law" and concluding, "[t]he view that courts should always defer to agency interpretations is . . a poor reconstruction of the instructions of the APA").

42 See generally 5 USC $\$ 706$.

43 See, for example, Walling v Portland Terminal Co, 330 US 148, 155 (1947) (Jackson concurring); Fishgold v Sullivan Drydock \& Repair Corp, 328 US 275, 290 (1946); Social Security Board v Nierotko, 327 US 358, 369 (1946); Mabee v White Plains 
early cases, like Skidmore, involved low-level administrators' interpretations of the Fair Labor Standards Act. ${ }^{44}$ The application of the Skidmore standard in these cases was quite confused as the Court sometimes cited the standard as justification for its exercise of independent judgment over the meaning of the statute. ${ }^{45}$ But at other times, the Court equated Skidmore deference with a requirement that the Court defer to reasonable agency interpretations of the statute. ${ }^{46}$ In fact, the very author of the Skidmore opinion, Justice Robert Jackson, became in later opinions the principal proponent of the view that the standard required heightened deference to agency interpretations. ${ }^{47}$

After the flurry of cases applying Skidmore deference in the mid-1940s, the Court essentially stopped applying the standard until the mid-1970s when the Court revived it in the Civil Rights Act case of General Electric Co $v$ Gilbert. ${ }^{48}$ In only four cases in this thirty-year period did the Court subject the agency's interpretation to the Skidmore requirement that it have "the power to persuade." 49 During this interlude, the Court in several cases gave greater deference to agency

Publishing Co, 327 US 178, 182 (1946); Jewell Ridge Coal Corp v Local Number 6167, United Mine Workers of America, 325 US 161, 169 (1945).

44 Four of the six early cases involved Supreme Court review of interpretations of the FLSA by low-level administrators. See Walling, 330 US at 149; Mabee, 327 US at 180-82; Jewell Ridge Coal Corp, 325 US at 169; Skidmore, 323 US at 137-38.

45 See cases cited in note 44 .

46 See, for example, Roland Electrical Co v Walling, 326 US 657, 676 (1946) (appearing to conflate the heightened deference standard frequently applied prior to Skidmore with the lesser Skidmore deference standard).

47 Walling, $330 \mathrm{US}$ at 154-55 (Jackson concurring).

48429 US 125, 141-42 (1976). In the period when Skidmore deference fell into disuse, the Court at times referred to factors of contemporaneity and consistency of agency interpretation as reasons to support granting deference. See Michael Asimow, Public Participation in the Adoption of Interpretive Rules and Policy Statements, 75 Mich L Rev 520, 566 (1977) (suggesting that courts tended to use many of these factors as "makeweights": "Having decided whether the interpretive regulation is valid, the court mentions all the factors it can muster that tend to support its decision"). Although the Court sometimes cited Skidmore as the source of these factors, the Court had in cases applying heightened deference prior to Skidmore considered these factors to be relevant as well. See Peter L. Strauss, Deference is Too Confusing-Let's Call Them Chevron Space and Skidmore Weight, 112 Colum L Rev 1143, 1154 (2012) (identifying the relevance of factors such as contemporaneity to the deference choice in cases dating back to the nineteenth century).

49 See Morton v Ruiz, 415 US 199, 237 (1974); United States v Pennsylvania Industrial Chemical Corp, 411 US 655, 674 (1973); United States v Stapf, 375 US 118, 127 n 11 (1963); Federal Maritime Board v Isbrandtsen Co, Inc, 356 US 481, 499-500 (1958). 
interpretations. This heightened deference standard received its most prominent application in the 1965 case of Udall $v$ Tallman. ${ }^{50}$ Deferring to the Secretary of Interior's interpretation of an Executive Order, Justice Earl Warren announced for a unanimous Court:

When faced with a problem of statutory construction, this Court shows great deference to the interpretation given the statute by the officers or agency charged with its administration. "To sustain the Commission's application of this statutory term, we need not find that its construction is the only reasonable one or even that it is the result we would have reached had the question arisen in the first instance in judicial proceedings." 51

This deference framework emerged as the leading standard of judicial review of agency interpretations in the period from the mid-1960s to the late-1970s. ${ }^{52}$ As suggested by the phrase "great deference," the Court usually deferred to agency interpretations under this standard. ${ }^{53}$

In the thirty years following the APA's enactment, the Court never explained why it gave heightened deference to some agency interpretations of ambiguous statutes and little to no deference to others. Legal scholars attempted to pick up the slack. Perhaps the most prominent administrative law scholar writing in this era, Kenneth Culp Davis, suggested that the level

\footnotetext{
50380 US 1 (1965).

51 Id at 16, quoting Unemployment Commission of Territory of Alaska v Aragon, 329 US $143,153(1946)$

52 For cases applying the "great deference" standard, see, for example Aluminum Co of America v Central Lincoln Peoples' Utility District, 467 US 380, 389-90 (1984); Blanding v DuBose, 454 US 393, 401 (1982); Federal Election Commission v Democratic Senatorial Campaign Committee, 454 US 27, 31-32 (1981); Howe v Smith, 452 US 473 , 485 (1981); Environmental Protection Agency v National Crushed Stone Association, 449 US 64, 83 (1980); United States v Rutherford, 442 US 544, 553 (1979); Oscar Mayer \& Co $v$ Evans, 441 US 750, 761 (1979); Gladstone, Realtors v Village of Bellwood, 441 US 91, 107 (1979); United States v Consumer Life Insurance Co, 430 US 725, 751-52 (1977); National Labor Relations Board v Bell Aerospace Co, Division of Textron, Inc, 416 US 267, 274-75 (1974); Johnson v Robison, 415 US 361, 367-68 (1974); Trafficante $v$ Metropolitan Life Insurance Co, 409 US 205, 210 (1972); Zuber v Allen, 396 US 168, 192 (1969); Zemel v Rusk, 381 US 1, 11 (1965). In addition, as discussed in further detail in Part II, the Court applied this "great deference" framework to agency interpretations of civil rights statutes, including Title VI and VII of the Civil Rights Act and the Voting Rights Act. See Part II.B.

53 See note 52.
} 
of deference turned on the nature of the agency action. In an article written immediately after the flurry of Supreme Court cases applying the Skidmore standard, Davis explained that the Court "has consistently held that judicial judgment should not be substituted for administrative judgment on questions within the agency's statutory power of rule-making." 54 Here, Davis was referring to agency authority under statutes to promulgate legislative rules through the notice-and-comment procedure. Davis suggested that deference to legislative rules accorded with congressional intent "that the determination of the content of the rules should be made by the agency and not by the courts." 55 Such intent, he explained, was absent in the context of interpretive rules. ${ }^{56}$ For these rules, "substitution of judicial judgment ... is always permissible." ${ }^{57}$ As a guide to such exercises of independent judicial judgment, Davis pointed to the standard articulated in Skidmore. ${ }^{58}$

Even though Davis cited to a handful of cases in which this deference dichotomy held, the subsequent pattern of case law did not accord with his explanation of judicial application of deference doctrine. In the flurry of cases in the late 1940s and the handful of cases thereafter, the Court did apply Skidmore deference exclusively to interpretive rules and policy statements. 59 But when "great deference" emerged as the leading deference framework in the mid-1960s, the Court applied it to these same forms of agency actions. ${ }^{60}$ The only

54 See Kenneth Culp Davis, Scope of Review of Federal Administrative Action, 50 Colum L Rev 559, 586 (1950).

55 Id at 587.

56 See United States Department of Justice, Attorney General's Manual on the Administrative Procedure Act at $30 \mathrm{n} 3$ (cited in note 1) (distinguishing between substantive rules issued pursuant to an agency's statutory authority and interpretative rules and general statements of policy that are not).

57 Davis, 50 Colum L Rev at 588 (cited in note 54 ).

58 See id. In 1958, Davis published the Administrative Law Treatise, which would serve as the most important statement of administrative procedure and the scope of review for the next quarter century. In the treatise, Davis re-asserted the dichotomy between heightened deference to legislative rules and minimal deference to interpretive rules first articulated in his 1950 law review article. See Kenneth Culp Davis, Administrative Law Treatise $§ 5.05$ at $314-15$ (West 1958). This statement of the law went virtually unchallenged in the literature perhaps because of the normative appeal of the dichotomy between the deference owed to interpretations adopted through more formalized procedures with public involvement and that owed to less formalized procedures without such public involvement.

59 See notes $43-45$.

60 See note 52 . 
pattern evidenced in the case law is one in which the Court relied more heavily on the Skidmore deference doctrine in a period surrounding the adoption of the APA and then on a much more deferential standard in a later period beginning in the mid-1960s with little regard to the form of the agency action. ${ }^{61}$

In the mid-1970s, the Supreme Court revived the Skidmore deference doctrine in a case involving the interpretation of the Civil Rights Act. ${ }^{62}$ A year after the Court revived Skidmore, the Court in Batterton v Francis ${ }^{63}$ appeared to pump some judicial life into Professor Davis's deference dichotomy. ${ }^{64}$ In a footnote to the decision, the Court distinguished between legislative rules "issued by an agency pursuant to statutory authority" that have

61 The dominance of the heightened deference standard by the early 1970 s was reflected most clearly in the efforts of Senator Dale Bumpers of Arkansas to amend the APA. The legislation that became known as the "Bumpers Amendment" was introduced in 1975 and called for amendment of the judicial review provision of the APA to require the reviewing court to decide de novo "all relevant questions of law." S 86, 95th Cong, 1st Sess (Jan 10, 1977), in 123 Cong Rec 639 (Jan 10, 1977) (describing a proposal to amend section 10(e) of the Administrative Procedure Act, 5 USC $\$ 706$ ). See also Carl MeGowan, Regulatory Analysis and Judicial Review, 42 Ohio St L J 627, 630 n 8 (1981) (describing different iterations of the Bumpers Amendment bill). Senator Bumpers argued that the amendment was necessary to restore the judicial authority established in Marbury $v$ Madison "to say what the law is," 5 US 137, 177 (1803), which had been eviscerated by courts "virtually rubber-stamping every agency action that comes before them for review." S 800, 94th Cong, 2d Sess (July 1, 1976), in 122 Cong Rec 22012 (July 1, 1976). Another supporter of the amendment explained, "[t]he Bumpers amendment is simple. It takes away the now court-recognized principle that a Federal agency's interpretation of Federal law is presumed to be correct." S 1477, 96th Cong, 1st Sess, in 125 Cong Rec 23498 (Sept 7, 1979) (providing the statement of Senator James Exon). The proponents of the Bumpers Amendment may have exaggerated the extent of judicial deference to agency interpretations of law and may have had an ulterior deregulatory motive in a context of proliferating economic and social regulations. See Cornelius B. Kennedy, The Bumpers Amendment: Regulating the Regulators, 67 ABA J 1639, 1641 (1981) (describing the impetus for the Bumpers Amendment); James T. O'Reilly, Deference Makes a Difference: A Study of Impacts of the Bumpers Judicial Review Amendment, 49 U Cin L Rev 739, 747-49 (1980) (describing the origins of the Bumpers Amendment). But the case law from the ten-year period to its introduction does suggest that the court regularly applied the "great deference" model and typically deferred to agency interpretations of statutes. See also Woodward and Levin, 31 Admin L Rev at 332 (cited in note 2) (describing the Court's present practice as one in which, when the Court reviews administrative actions, it "frequently begin[s] [its] analysis of a disputed question of construction by assuming that the agency's interpretation is correct and then inquiring whether other factors outweigh the agency's view"); Asimow, $75 \mathrm{Mich}$ L Rev at 565-66 (cited in note 48) (describing recent developments in judicial review of interpretive rules and noting that "courts nearly always defer to interpretive regulations" and that "[c]ourts seldom employ the sort of free-wheeling substitution of judgment that the traditional model permits").

62 See note 52 and accompanying text.

63432 US 416 (1977).

64 Id. 
"the force and effect of law" and interpretive rules that presumptively lack these qualities. ${ }^{65}$ The latter form of agency interpretations, the Court offered in dictum, is accorded "[v]arying degrees of deference ... based on such factors as the timing and consistency of the agency's position, and the nature of its expertise." 66

Despite suggesting a standardization of deference doctrine in the Batterton footnote, ${ }^{67}$ the Court after Batterton continued to alternate between the "great deference" and Skidmore deference standard without any apparent rhyme or reason. ${ }^{68}$ Scholars trying to make sense of the seeming randomness in judicial applications of deference doctrines suggested that the two standards were in fact one-that the "great deference" standard was merely a variation of Skidmore deference. ${ }^{69}$ But while the Court did at times conflate the two standards, there is

65 See Batterton, 432 US at 425 n 9 . See also John S. Moot, Comment, An Analysis of Judicial Deference to EEOC Interpretive Guidelines, 1 Admin L J 213, 217 (1987) (describing Batterton as the first instance in which the Court distinguished between interpretative and legislative rules).

66 See Batterton, 432 US at 425 n 9.

67 Arguably, the Court in Batterton was not applying the deference dichotomy at all. Instead, the Court seemed to be drawing a distinction between interpretations promulgated on the basis of expressly delegated congressional authority and rules that are not. As to rules promulgated pursuant to an implicit delegation of authority, like those that arise in the context of statutory ambiguity, the Court in Batterton never committed to a standard of deference. See id at $425-26$

68 The post-Batterton, pre-Chevron cases applying the "great deference" standard include Aluminum Co of America, 467 US at 389-90; Blanding, 454 US at 401, Democratic Senatorial Campaign Committee, 454 US at 31-32; Howe, 452 US at 485; National Crushed Stone Association, 449 US at 83; Rutherford, 442 US at 553; Evans, 441 US at 761; Gladstone Realtors, 441 US at 107. The post-Batterton, pre-Chevron cases applying Skidmore deference include St. Martin Evangelical Lutheran Church v South Dakota, 451 US 772, 783 n 13 (1981); Watt v Alaska, 451 US 259, 272-73 (1981); Steadman v Securities and Exchange Commission, 450 US 91, 103-04 (1981); City of Los Angeles Department of Water and Power v Manhart, 435 US 702, $714 \mathrm{n} 26$ (1978); Adamo Wrecking Co v United States, 434 US 275, 287-89 n 5 (1978). See also Goering, $36 \mathrm{~J}$ Legis at 42 (cited in note 25) ("In the early 1980 's, the Supreme Court's decisions reviewing administrative interpretations typically followed one of ... two deference frameworks and commonly ignored the other, with little or no explanation.").

69 See, for example, Thomas W. Merrill, Judicial Deference to Executive Precedent, 101 Yale L J 969, 972-74 (1992) (describing the pre-Chevron regime as an amalgamation of the Skidmore and "great deference" frameworks); but see Goering, 36 J Legis at 42 (cited in note 25) (arguing that in the period between Batterton and Chevron, "the Supreme Court's decisions reviewing administrative interpretations typically followed one of these two deference frameworks and commonly ignored the other, with little or no explanation"). 
significant evidence that the justices did not consider them equivalent. ${ }^{70}$

\section{B. Judicial Deference Choices after the Chevron Revolution}

The so-called "revolution" in deference doctrine came in 1984 when the Court famously established a two-step framework for judicial review of agency interpretations in Chevron USA, Inc v Natural Resources Defense Council, Inc. ${ }^{71}$ At step one, the Court determines whether Congress had a clear intent with respect to the particular issue addressed by the agency. ${ }^{72}$ If the intent is clear, the Court and agency must give effect to the unambiguous preferences of Congress. ${ }^{73}$ But if the statute is silent or ambiguous on the particular question, courts should proceed to step two and decide "whether the agency's answer is based on a permissible construction of the statute." 74 From the perspective of deference doctrine, the Chevron twostep framework was not really anything new. Courts had always rejected agency interpretations inconsistent with the clear intent of Congress. ${ }^{75}$ The requirement that agency interpretations of ambiguous statutes be merely permissible is really no different than the "great deference" standard, which notes that courts need not find that the agency "construction is the only reasonable one, or even that it is the result [the Court] would have reached had the question arisen in the first instance in judicial proceedings." 76

Importantly, however, the Court in Chevron appeared to reject the deference dichotomy. Chevron seemed to establish a uniform deference doctrine to be applied to all agency interpretations of ambiguous statutes on the basis of an implicit

70 See Part II.A.

71467 US 837 (1984).

72 Id at $842-43$.

73 Id.

74 Id at 843 .

75 See, for example, Espinoza v Farah Manufacturing Co, 414 US 86, 88-89 (1973) (holding that an EEOC interpretive guideline was not entitled to great deference because it was inconsistent with the clear intent of Congress). See also Hickman and Krueger, In Search of the Modern Skidmore Standard, 107 Colum L Rev at 1241 (2007) (cited in note 17) ("Even before Cheuron, if the meaning of a statute was clear, there was no opportunity for an agency to claim judicial deference.").

76 Udall, 380 US at 16. In fact, in cases subsequent to Cheuron, the Court did not treat the deference model as unique as it continued to rely on pre-Chevron cases to support the application of heightened deference. 
delegation theory-when Congress has left gaps and ambiguities in a statute, it has implicitly delegated to the agencies responsible for administering the statute the authority to fill those gaps and clarify those ambiguities. ${ }^{77}$ Consistent with this implicit delegation theory, the Court in the years immediately following Chevron applied the two-step framework indiscriminately to both legislative and interpretive rules construing ambiguous statutes. ${ }^{78}$

But the Court in this period also limited Chevron deference's apparent broad domain, with little explanation. Beginning with cases reviewing agency interpretations of Title VII of the Civil Rights Act, the Court revived Skidmore deference for a second time. ${ }^{79}$ Between Chevron in 1984 and Christensen v Harris County in 2000, most of the cases in which the Court applied Skidmore deference involved interpretations of civil rights statutes - an issue I turn to in Part II.

Noting the Court's failure to apply Chevron in the civil rights context, some scholars again turned to the deference dichotomy. To the extent the Court had refused to defer to interpretive rules offered by civil rights agencies, these scholars saw the move as a justified one. They argued that uniform application of a heightened deference standard to both legislative and interpretive rules would create incentives for resource-constrained agencies to proceed via the path of least resistance. If the Court applied Chevron deference uniformly, agencies would simply bypass the more onerous notice-andcomment process and substitute interpretive rules for legislative rules. ${ }^{80}$ This workaround would diminish public participation in

77 The Court explained, "Sometimes the legislative delegation to an agency on a particular question is implicit rather than explicit. In such a case, a court may not substitute its own construction of a statutory provision for a reasonable interpretation made by the administrator of an agency." Chevron, 467 US at 844.

78 For cases in which the Court applied Chevron deference to interpretive and other non-legislative rules, see, for example, NationsBank of North Carolina, NA v Variable Annuity Life Insurance Co, 513 US 251 (1995); Pension Benefit Guaranty Corp v The LTV Corp, 496 US 633 (1990); Mead Corp v Tilley, 490 US 714 (1989); Young v Community Nutrition Institute, 476 US 974 (1986); Federal Deposit Insurance Corp v Philadelphia Gear Corp, 476 US 426 (1986).

79 See note 222 and accompanying text.

80 Beginning in the 1970 s, procedural demands on notice-and-comment rulemaking from the judicial and executive branches made the process much more onerous. See Richard J. Pierce Jr, Seven Ways to Ossify Agency Rulemaking, 47 Admin L Rev 59, 6265 (1995). As a result, "the simple, efficient notice and comment process" was transformed "into an extraordinarily lengthy, complicated, and expensive process." Id at 
agency decision-making processes, the most celebrated innovation of the Administrative Procedures Act. ${ }^{81}$ So when the Court applied Skidmore deference to interpretive rules in the civil rights context, it was a welcome revival of a deference dichotomy that subjected agencies to a "pay me now, or pay me later" mandate. ${ }^{82}$ Agencies could pay costs in terms of resources and time now by engaging in the onerous rulemaking process and receive heightened deference for their statutory interpretations under the Chevron doctrine. Or alternatively, agencies could bypass the notice-and-comment process through the issuance of interpretive rules but pay costs later by having their interpretations subjected to greater judicial scrutiny under the Skidmore standard.

Proponents of the deference dichotomy appeared to secure an important victory when the Court formally enshrined it into judicial doctrine in cases decided during the first two years of the twenty-first century, Christensen v Harris County ${ }^{83}$ and United States v Mead Corp. ${ }^{84}$ Christensen and Mead involved questions about the level of deference owed to agency interpretations in the form of interpretive rules. The Court, citing an updated edition of Kenneth Culp Davis's administrative law treatise and a few post-Chevron cases (while ignoring other inconsistent post-Chevron cases ${ }^{85}$ ), held that a Department of Labor opinion letter and United States Customs Services tariff classification rulings were entitled to only Skidmore deference. ${ }^{86}$ The Court explained that when there is a congressional delegation of authority to the agency, Chevron deference applied to the agency's interpretations of statutes. ${ }^{87}$

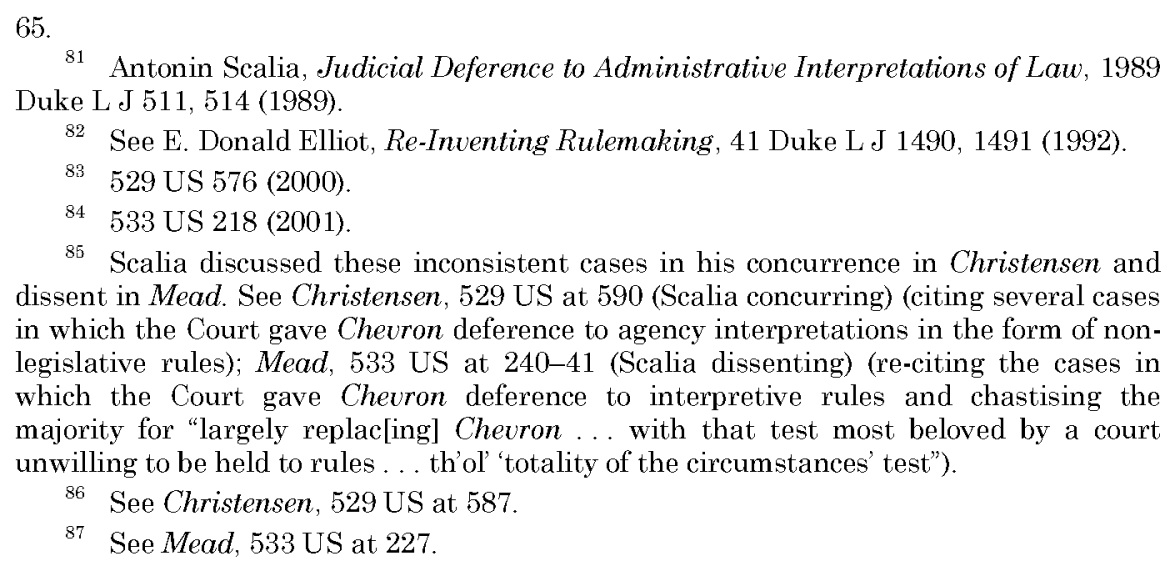

85 Scalia discussed these inconsistent cases in his concurrence in Christensen and dissent in Mead. See Christensen, 529 US at 590 (Scalia concurring) (citing several cases in which the Court gave Chevron deference to agency interpretations in the form of nonlegislative rules); Mead, 533 US at 240-41 (Scalia dissenting) (re-citing the cases in which the Court gave Cheuron deference to interpretive rules and chastising the majority for "largely replac[ing] Chevron ... with that test most beloved by a court unwilling to be held to rules... th'ol' 'totality of the circumstances' test").

86 See Christensen, 529 US at 587.

87 See Mead, 533 US at 227. 
Such delegation is indicative of a congressional intent to give the agency interpretations the force of law. ${ }^{88}$ But when an agency advances an interpretation in the absence of a congressional delegation of authority, the Court will defer to that interpretation only insofar as it is persuasive under the Skidmore standard. ${ }^{89}$ While the Court gave itself some room to navigate around the deference dichotomy, ${ }^{90}$ many viewed the two cases as complete acceptance of what Davis and others had advocated for a half-century. ${ }^{91}$

Since Christensen and Mead, the Court has applied the deference dichotomy with greater consistency. ${ }^{92}$ When it has applied a deference model, the Court seems to have been more consistent in applying Skidmore or lesser deference to interpretive rules and heightened Chevron deference to legislative rules. ${ }^{93}$ But the Court has continued to deviate from the deference dichotomy in some cases. In particular, the Court has proved reluctant to apply Chevron deference to agency interpretations of civil rights statutes in the form of legislative rules. It has used a variety of workarounds to avoid giving Chevron deference to these agency interpretations-

88 See id.

89 See id at $227-28$.

90 For example, the Court explained that for purposes of applying Chevron deference, congressional delegations of authority do not necessarily have to be explicit, as other factors such as the formality of the procedure involved in the adoption of the agency rule may indicate a congressional intent to delegate. But the Court emphasized that "express congressional authorizations to engage in rulemaking or formal adjudication" are "a very good indicator of delegation meriting Chevron treatment." Id at 229 .

91 David Barron and Elena Kagan offered an alternative interpretation of Christensen and Mead suggesting that the cases established "an internal agency nondelegation doctrine" that limited the ability of agency officials to sub-delegate decisionmaking to others. See David J. Barron and Elena Kagan, Chevron's Nondelegation Doctrine, $2001 \mathrm{~S}$ Ct Rev 201, 201-04 (2001). See also Cass R. Sunstein, Beyond Marbury: The Executive's Power to Say What the Law Is, 115 Yale L J 2580, 2603 (2006) (arguing that "Mead should be seen as an unusual case in an exceedingly unusual setting, in which low-level administrators were required to produce thousands of rulings, in a way that undermined the view that the executive branch should receive deference").

92 See Hickman, 66 Vand L Rev at 489 (cited in note 2).

98 I have not found an empirical study that contrasts the application of the deference dichotomy pre- and post-Mead. But logic would suggest that since the deference dichotomy was not established in doctrine prior to Mead that the Court would be more consistent in its application of the dichotomy after Mead. This question is ripe for empirical examination, as it would provide more insight on the effect of doctrine on judicial decision-making. 
workarounds the Court appears to be less inclined to use in other contexts. ${ }^{94}$

The history of judicial application of deference doctrine to agency interpretations has thus been one where the Court has largely failed to follow any single, coherent deference framework, whether by adhering to the deference dichotomy or by consistently following either of its own two prior formulations, the "great deference" or Skidmore's "power to persuade" standard.

Explanations for the Court's actual deference patterns have been limited thus far by the tendency of scholars to focus on judicial application of deference doctrine at the macro-level across all administrative domains or at the micro-level examining particular statutes and agencies. As I show in the next section, these analyses have provided explanations that are either incomplete or overly speculative.

\section{Current Explanations for the Court's Deference Patterns}

Since the deference dichotomy provides at best only a partial account of Supreme Court applications of deference, how can we understand the Court's actual pattern of deference? At the macro level, scholars assessing judicial application of deference doctrines in all administrative law domains have addressed this question only indirectly, providing incomplete and contradictory answers. At the micro level, scholars evaluating judicial application of deference doctrine in specific regulatory domains have addressed the question more directly, but their answers are either speculative or cannot be generalized to other contexts.

1. Macro-level accounts.

Some scholars have used quantitative empirical methods to analyze whether political ideology predicts individual justices' votes to accord heightened deference across a broad set of cases. Unfortunately, the two primary studies to date have arrived at conflicting results.

In one study, Thomas Miles and Cass Sunstein examined all eighty-four decisions between 1980 and 2005 in which the

94 See Part II.B. 4 
Supreme Court reviewed agency interpretations of statutes and the majority either applied Chevron deference or the concurring or dissenting justices argued that Chevron deference should have applied. ${ }^{95}$ Miles and Sunstein found "little variation overall in the rate at which the ... justices voted to apply Chevron." 96 From this finding, the scholars surmised that the justices were constrained by doctrine to apply Chevron in the overwhelming majority of the cases. ${ }^{97}$ Judicial deviations from the application of Chevron had little to do with ideology.

In the second study, Connor Raso and William Eskridge came to the opposite conclusion. The scholars asked whether the Court treated deference doctrines as precedent with stare decisis effect or as canons of construction in which ideological factors influence the application of deference doctrine. ${ }^{98}$ Examining 667 Supreme Court cases involving agency interpretations of federal statutes between Chevron (1984) and Hamdan v Rumsfeld ${ }^{99}$ (2006), the authors found that the "justices systematically support less deferential regimes for policies with which they disagree." 100 Raso and Eskridge concluded, "ideological concerns influence application of deference doctrine." 101

95 See Thomas J. Miles and Cass R. Sunstein, Do Judges Make Regulatory Policy? An Empirical Investigation of Chevron, 73 U Chi L Rev 823, 825 (2006).

96 Id at 843 .

97 See id at 843-44 (acknowledging the tentative nature of these conclusions because of the small sample size of cases).

98 Connor N. Raso and William N. Eskridge Jr., Chevron as a Canon, Not a Precedent: An Empirical Study of What Motivates Justices in Agency Deference Cases, 110 Colum L Rev 1727, 1732 (2010).

$99126 \mathrm{~S} \mathrm{Ct} 2749$ (2006).

100 Raso and Eskridge, 110 Colum L Rev at 1784 (cited in note 98). The scholars found the "correlation between ideological preferences and deference regime preferences is 0.92 , with liberal justices favoring less deferential regimes than the conservatives when conservative agency interpretations are at issue." And "[w] hen only liberal agency policies are analyzed, the results are reversed: Liberals support more deferential regimes and conservatives support less deferential regimes." Id at 1787.

101 Id at 1734. The conflicting findings are likely the result of the differences in the data used. Miles and Sunstein focused on a much narrower subset of cases involving explicit controversies about the applicability of Chevron deference while Raso and Eskridge analyzed a much broader set of cases for which a variety of deference doctrines were potentially applicable. It could be the case that once Raso and Eskridge narrowed their dataset to cases in which justices explicitly contested whether Chevron applied, they would reach the same conclusions as Miles and Sunstein-that these disputes about the choice of deference were not driven by ideology. In two other studies, Thomas Merrill examined all Supreme Court decisions between 1981 and 1990 and found that the Court often ignored Cheuron, only applying its deference doctrine to one third of the postChevron cases in which at least one justice found that the case raised an issue of deference. See Thomas W. Merrill, 101 Yale L J at 982-85 (cited in note 69). Merrill did 
These conflicting macro-level empirical results about the influence of ideology on judicial deference choices leave us searching for answers. The question ultimately may not be conducive to quantitative analysis as factors not as easily quantifiable as ideology may be influencing the justices' deference choices. Attempting to explain the Court's choices in more nuanced ways, other scholars have looked to judicial application of deference regimes in agency-specific contexts.

\section{Agency-specific accounts.}

Agency-specific accounts have focused principally on the post-Chevron application of deference doctrine in three administrative law contexts - tax, environmental, and employment discrimination law. ${ }^{102}$ Scholars in the tax context

not offer a theory to explain why the Court applied Chevron so infrequently. William Eskridge and Lauren Baer examined all 1,014 cases between Chevron in 1984 and Hamdan v Rumsfeld in 2005 "in which an agency interpretation of a statute was at issue." They found that the Court applied Cheuron deference in 8.3 percent of the cases, Skidmore deference in 6.7 percent of the cases and no deference at all in 53.6 percent of the cases. William N. Eskridge Jr and Lauren E. Baer, Continuum of Deference: Supreme Court Treatment of Agency Statutory Interpretations from Chevron to Hamdan, 96 Georgetown L J 1083, 1089-90 (2008). Eskridge and Baer concluded, "[T]he Court invokes deference regimes in a manner that is seemingly sporadic and haphazard." Id at 1137.

102 See generally Margaret H. Lemos, The Consequences of Congress's Choice of Delegate: Judicial and Agency Interpretations of Title VII, 63 Vand L Rev 363 (2010); Jason J. Czarnezki, An Empirical Investigation of Judicial Decisionmaking, Statutory Interpretation, and the Chevron Doctrine in Environmental Law, 79 U Colo L Rev 767 (2008); Kristen E. Hickman, The Need for Mead: Rejecting Tax Exceptionalism in Judicial Deference, 90 Minn L Rev 1537 (2006); Melissa Hart, Skepticism and Expertise: The Supreme Court and the EEOC, 74 Fordham L Rev 1937 (2006); Rebecca Hanner White, Deference and Disability Discrimination, 99 Mich L Rev 532 (2000); Theodore W. Wern, Note, Judicial Deference to EEOC Interpretations of the Civil Rights Act, the ADA, and the ADEA: Is the EEOC a Second Class Agency?, 60 Ohio St L J 1533 (1999); Richard L. Revesz, Environmental Regulation, Ideology, and the D.C. Circuit, 83 Va L Rev 1717 (1997); David A. Brennen, Treasury Regulations and Judicial Deference in the Post-Chevron Era, 13 Ga St U L Rev 387 (1997); John F. Coverdale, Court Review of Tax Regulations and Revenue Rulings in the Chevron Era, 64 Geo Wash L Rev 35 (1995); Linda Galler, Judicial Deference to Revenue Rulings: Reconciling Divergent Standards, 56 Ohio St L J 1037 (1995); Rebecca Hanner White, The EEOC, the Courts and Employment Discrimination Policy: Recognizing the Agency's Leading Role in Statutory Interpretation, 1995 Utah L Rev 51 (1995); Jamie A. Yavelberg, The Revival of Skidmore v. Swift: Judicial Deference to Agency Interpretations After EEOC v. Aramco, 42 Duke L J 166 (1992); Moot, 1 Admin L J at 213 (cited in note 65). One study also examined deference choices in the immigration context. Adam B. Cox, Deference, Delegation, and Immigration Law, 74 U Chi L Rev 1671, 1679-82 (2007) (examining Judge Richard Posner's jurisprudence reviewing agency adjudications in immigration cases and suggesting that "skepticism in immigration cases appears to be driven by a judgment about comparative institutional competence"). 
have tried to explain the Supreme Court's decision to leave unresolved the deference owed to Internal Revenue Service interpretations of the tax code as well as broader judicial deviations from the deference dichotomy. ${ }^{103}$ The Court, without explanation, typically gives heightened deference to the agency's interpretation of the tax code even when the interpretations do not take the form of legislative rules. ${ }^{104}$ Rather than attributing deviations from the deference dichotomy to ideology, tax scholars have suggested that heightened deference in tax cases may represent the judicial recognition of the IRS's comparative advantage in resolving complex technical questions of tax law. ${ }^{105}$

Other scholars have examined appellate courts' review of the Environmental Protection Agency's interpretations of environmental statutes. One study found that the appellate courts show "a strong willingness to defer, under any doctrine or framework, to agency action when environmental scientific expertise is required." ${ }^{106}$ Similar to the tax context, this evidence suggests that judicial perceptions of comparative agency expertise may influence the decisions of when to defer under either of the major deference doctrines. The same study also found some evidence that courts use Chevron deference strategically to achieve particular ideological outcomes. ${ }^{107}$

Finally, scholars examining the employment discrimination context have focused principally on the Equal Employment Opportunity Commission's interpretation of employment discrimination statutes. These studies also found recurring Supreme Court deviations from the deference dichotomy and

\footnotetext{
${ }_{103}$ See, for example, Hickman, 90 Minn L Rev at 1588 (cited in note 102) ("[T]he Court's post-Chevron analysis in both tax and non-tax deference cases is devoid of any hint that the legislative/interpretive distinction governs the assessment of Chevron's applicability."); Galler, Judicial Deference to Revenue Rulings, 56 Ohio St L J at 1074 (cited in note 102) (noting the Supreme Court's failure to articulate a deference standard in the tax cases).

104 See Galler, 56 Ohio St L J at 1042 (cited in note 102) ("[C]ourts are increasingly likely to treat [informal] revenue rulings like regulations by deferring to IRS positions that are set forth in the revenue ruling format."). Scholars have referred to this as "tax exceptionalism." See, for example, Hickman, 90 Minn L Rev at 1541 (cited in note 102).

${ }^{105}$ See Hickman, 90 Minn L Rev at 1600 (cited in note 102). ("[T]he expertise necessary in interpreting the Code ... justifies imputing to Congress the decision to grant Treasury such broad, primary interpretative authority."). See also Galler, 56 Ohio St L J at 1077-79 (cited in note 102) (speculating that the complexity of the tax code was the reason for judges being more willing to defer to IRS revenue rulings).

106 See Czarnezki, 79 U Colo L Rev at 771 (cited in note 102).

107 Id at $795-96$.
} 
have offered a variety of explanations for the inconsistencies. ${ }^{108}$ These include the non-technical nature of the subject, the importance of the employment discrimination statutes, the lack of judicial regard for the expertise of the EEOC, and suspicion about the EEOC's agenda. 109 These explanations are, however, speculative as the supporting evidence is somewhat limited. ${ }^{110}$

Focusing on judicial review of specific agency interpretations offers the promise of identifying sources of deviations from the deference dichotomy that are likely to be context-specific. But the micro-level assessments have not offered a systematic account of why courts deviate from the deference dichotomy. A major challenge is disentangling judicial views of particular agencies from other reasons for the judicial applications of particular deference doctrines. It is difficult to know whether judicial deviations from the deference dichotomy are driven by views of the EEOC, EPA, or IRS, the statutes they administer, or whether some other factors account for the Court's choice about deference doctrine.

\section{JUDICIAL RESISTANCE TO ADMINISTRATIVE CONSTITUTIONALISM}

Over the past forty years, many of the Court's most glaring inconsistencies in its application of deference doctrine have arisen in the context of judicial review of agency interpretations of civil rights statutes. In the mid-1970s, the Court broke from its prior pattern of "great deference" and began to apply Skidmore deference to agencies' interpretations of the meaning of discrimination or discriminatory effect under civil rights statutes. Later, after the so-called Chevron revolution in deference doctrine, the Court again revived Skidmore deference applying it to agency interpretations of discrimination and discriminatory purpose under civil rights statutes. Finally, after the Court firmly established the deference dichotomy in

\footnotetext{
108 See Hart, 74 Fordham L Rev at 1937 (cited in note 102); White, 99 Mich L Rev at 569-71 (cited in note 102); Wern, 60 Ohio St L J at 1578-80 (cited in note 102).

109 See, for example, Hart, Skepticism and Expertise, 74 Fordham L Rev at 1937 (cited in note 102); White, Deference and Disability Discrimination, 99 Mich L Rev at 569-71 (cited in note 102); Wern, Judicial Deference to EEOC Interpretations, 60 Ohio St $\mathrm{L} \mathrm{J}$ at 1578-80 (cited in note 102).

110 See text accompanying note 109 (providing explanations for deviations from deference dichotomy in speculative terms).
} 
doctrine, the Court continued to deny heightened deference to legislative rules defining the classes of individuals entitled to special protection under the civil rights statutes.

These breakdowns in the deference dichotomy are best understood as judicial resistance to administrative constitutionalism. Regardless of the form that the agency interpretation took or what precedent dictated, the Court in these periods applied a framework of minimal or no deference when the agency's statutory interpretive judgment implicated an ongoing constitutional controversy.

In thus resisting administrative constitutionalism, the Court asserted its authority over constitutional meaning. Like the Court's rejection of congressional authority under Section 5 of the Fourteenth Amendment to define the substance of the Equal Protection and Due Process Clauses, the Court through resistance to administrative constitutionalism has denied agencies similar authority over constitutional meaning. In this respect, such resistance represents another assertion of judicial supremacy - the idea that the Court is the final and exclusive interpreter of the Constitution. The Court's assertion of judicial supremacy in its review of agency interpretations has had a profound impact on the evolving meaning of civil rights statutes, one that will likely continue into the future.

In the following, I argue that judicial resistance to administrative constitutionalism explains the Court's deference pattern by examining the Court's review of agency interpretations of civil rights statutes in three eras: preChevron, post-Chevron, and the Christensen-Mead eras. I focus on judicial review of agencies' interpretations of five major civil rights statutes-Title VI and Title VII of the Civil Rights Act, the Voting Rights Act, the Age Discrimination in Employment Act, and the Americans with Disabilities Act. I then identify the link between judicial resistance to administrative constitutionalism and judicial supremacy. I conclude this Part by exploring the implications of judicial resistance to administrative constitutionalism for statutory civil rights' past and future. 
A. Judicial Review of Agency Interpretations of Civil Rights Statutes

The dominant account to date indicates that the form of agency action-whether it is in the form of an interpretive rule or a legislative rule-dictates judicial choices about what level of deference to apply. But in the civil rights domain, neither the deference dichotomy, nor any competing explanations, whether found in the Court's precedent or in the more "realist" explanations like ideology or the Court's appraisal of particular agencies' technical expertise, seem to explain such choices. What the case law instead evidences is an alternative axis for judicial deference choices that is often in tension with the deference dichotomy-judicial resistance to administrative constitutionalism.

1. The Civil Rights Statutes of the 1960s.

The Civil Rights Act of 1964 and the Voting Rights Act of 1965 represent two of the most important anti-discrimination statutes that Congress has ever enacted. Titles VI and VII of the Civil Rights Act and Section 5 of the Voting Rights Act were focal points of agency-judicial contestation over statutory meaning in the pre-Chevron era. ${ }^{111}$ All three statutes left critical terms undefined, thus vesting significant powers in the implementing agencies and provoking tension when courts and agencies disagreed.

Title VI of the Civil Rights Act prohibits racial discrimination in "any program or activity receiving Federal financial assistance." "112 The title empowers agencies responsible for providing federal financial assistance to government programs or activities (twenty-two agencies at the time of enactment) to enforce the title through the issuance of presidentially-approved "rules, regulations, or orders of general applicability." 113 The agencies have authority to terminate federal funds if "there has been an express finding on the record, after opportunity for hearing, of a failure to comply with [the

\footnotetext{
111 See 42 USC $\$ \S 2000 d, 2000 \mathrm{e}, 1973 \mathrm{~b}(\mathrm{a})(1), 1973 \mathrm{c}(\mathrm{a})$.

11242 USC $\$ 2000 \mathrm{~d}$.

11342 USC $\$ 2000 \mathrm{~d}-1$.
} 
regulatory] requirement." 114 Because of challenges associated with the coordination of multiple-agency enforcement of the statute, several of the agencies sub-delegated (with the encouragement of the Department of Justice) their enforcement authority to the Department of Health, Education, and Welfare (HEW). ${ }^{115} \mathrm{HEW}$ emerged as the lead administrator of Title VI and employed its enforcement authority to not only issue rules and regulations in accordance with the statute, but to also issue guidelines interpreting the statute that did not require presidential approval. ${ }^{116}$

Title VII of the Civil Rights Act prohibits discrimination in employment on the basis of race, national origin, religion, and sex. ${ }^{117}$ The principal provision of the title, section 703(a)(1) makes it unlawful for the employer "to fail or refuse to hire or to discharge any individual, or otherwise to discriminate against any individual with respect to his compensation, terms, conditions, or privileges of employment, because of such individual's race, color, religion, sex, or national origin." 118 Unlike Title VI, Title VII primarily relies on a private litigation model of enforcement. ${ }^{119}$ The Equal Employment Opportunity Commission, which was created to administer the Act, has the authority to investigate a charge of a Title VII violation and determine whether there is "reasonable cause to believe that the charge is true." 120 Under the original 1964 Act, once the Commission made the determination of reasonable cause, it only had the authority to eliminate the unlawful employment practice through informal methods of "conference, conciliation, and persuasion." ${ }^{121}$ In the 1972 amendment to the Act, Congress gave the Commission the authority to file suit against 
employers. ${ }^{122}$ Congress, however, denied the commission the authority to issue cease-and-desist orders and only gave the commission authority to promulgate "suitable procedural regulations." 123 Nonetheless, despite the absence of explicit statutory authority, the Commission did issue guidelines interpreting Title VII resting its exercise of interpretive rulemaking authority on its power to make reasonable cause determinations. ${ }^{124}$

Finally, Section 5 of the Voting Rights Act of 1965 required that jurisdictions with a history of discrimination, or "covered jurisdictions," obtain approval, or "preclearance," for any change to a "voting qualification or prerequisite to voting, or standard, practice, or procedure with respect to voting" from either the United States Attorney General or the United States District Court for the District of Columbia. ${ }^{125}$ To obtain preclearance for the voting change, the covered jurisdiction had the burden of proving that the new voting standard or procedure "does not have the purpose and will not have the effect of denying or abridging the right to vote on account of race." ${ }^{26}$ Jurisdictions usually submitted their voting changes first to the Attorney General since it often required less time to obtain Attorney General approval. As a result, the Attorney General through the Civil Rights Division of the Department of Justice took the lead role in administering the preclearance process. In this role, the Attorney General either precleared the change or rejected the change through objection letters that offered an explanation of the reason for the disapproval. ${ }^{127}$ In addition to its preclearance authority over voting changes, the Attorney General, like HEW

122 Id.

${ }^{123} 42$ USC $\$ 2000$-12(a). See also White, 1995 Utah L Rev at 60 (cited in note 102) (describing the mysterious adoption of the provision limiting EEOC rulemaking authority to procedural regulations).

124 See Moot, 1 Admin L J at 219-21 (cited in note 65) (describing the multiple bases for the EEOC's authority to issue interpretative guidelines).

${ }^{125} 42$ USC $\$ 1973 \mathrm{~b}(\mathrm{a})(1) ; 42$ USC $\$ 1973 \mathrm{c}(\mathrm{a})$.

12642 USC $\$ 1973 \mathrm{a}(\mathrm{c})$.

${ }_{127}$ See Hiroshi Motomura, Preclearance Under Section Five of the Voting Rights Act, 61 NC L Rev 189, 192 (1983). If the Attorney General objected, the covered jurisdiction could either make modifications to the voting change to satisfy the objection or seek approval for the change from the federal district court for the District of Columbia. See id at 191. 
and the EEOC, also issued guidelines interpreting ambiguities in the statute. ${ }^{128}$

Congress failed to clearly define critical terms in all three of these statutory provisions. For example, in Title VI and VII, Congress failed to clearly define discrimination leaving unanswered whether proof of discrimination required evidence of intent or merely effect. ${ }^{129}$ In Section 5 of the VRA, Congress left ambiguous the meaning of discriminatory purpose and effect. ${ }^{130}$ The statute failed to establish whether the baseline for measuring the purpose or effect of a voting change was what existed prior to the change or some hypothetical nondiscriminatory state. These ambiguities emerged as the subject of litigation in the years following the enactment of the statutes. On several occasions, the Supreme Court and the responsible agencies played competing roles in resolving these ambiguities.

2. The pre-Chevron era: civil rights and the judicial abandonment of "great deference."

a) Supreme Court application of "great deference." Initial struggles over the meaning of the civil rights statutes occurred in the early 1970 s when heightened deference frameworks predominated. As described in Part I, the Court in that period was willing to give "great deference" to all forms of agency interpretive actions-adjudications, legislative rules, and non-legislative rules. ${ }^{131}$ During that early period, the Court similarly applied "great deference" to early agency interpretations of Titles VI and VII of the Civil Rights Act and

128 See J. Morgan Kousser, The Strange, Ironic Career of Section 5 of the Voting Rights Act, 1965-2007, 86 Tex L Rev 667, 689 (2008) (describing the Department of Justice's early role in issuing guidelines interpreting Section 5 of the VRA).

129 Title VI states, "No person in the United States shall, on the ground of race, color, or national origin, be excluded from participation in, be denied the benefits of, or be subjected to discrimination under any program or activity receiving Federal financial assistance." 42 USC $\$ 2000 \mathrm{~d}$. The principal provision of Title VII states, "[i]t shall be an unlawful employment practice for an employer (1) to fail or refuse to hire or discharge any individual, or otherwise to discriminate against any individual with respect to his compensation, terms, conditions, or privileges of employment, because of such individual's race, color, religion, sex, or national origin." 42 USC $\$ 2000 \mathrm{e}-2$ (a)(1).

130 Section 5 of the Voting Rights Act prohibits any covered jurisdiction from adopting a voting change "that has the purpose or will have the effect of diminishing the ability of any citizen of the United States on account of race or color." 42 USC $\$ 1973 \mathrm{c}$.

131 See Part I.A. 
the Voting Rights Act, even though all of the relevant agency interpretations were in the form of non-legislative rules. ${ }^{132}$

Title VII of the Civil Rights Act represented the most active arena of civil rights litigation. This made sense in light of the fact that it is the only one of the three statutes for which Congress expressed a clear preference for a private litigation model of enforcement. The Equal Employment Opportunity Commission, however, was not absent from decisions about the meaning of the statute despite its limited enforcement authority under the Act. One of the principal means by which the EEOC asserted its authority over statutory meaning was through the issuance of interpretive guidelines. In the two years immediately following the enactment of Title VII, the EEOC issued guidelines on discrimination because of sex and religion and on employee selection procedures. ${ }^{133}$ Even though the EEOC lacked explicit statutory authority to issue these guidelines, the Supreme Court in four early cases accorded the agency's interpretations "great deference."

In the landmark 1971 case of Griggs v Duke Power Co, ${ }^{134}$ the Court addressed whether it was permissible under Title VII for employers to require that employees have a high school education or pass standardized intelligence tests as a condition for employment in, and transfer to, higher paying departments. These requirements disproportionately excluded African American applicants and employees. The case implicated the meaning of two statutory provisions: Section 703(a)'s prohibition on employment practices that discriminate on account of race and Section 703(h)'s authorization for employers to use "any professional developed ability test." ${ }^{35}$ The EEOC issued guidelines on employee selection procedures that interpreted Section 703(h) to permit employment tests that disparately harmed African Americans only if they were job-related. ${ }^{136}$ The Court, citing Udall $v$ Tallman, determined that this interpretation by "the enforcing agency" was "entitled to great

\footnotetext{
132 See, for example, Griggs v Duke Power Co, 401 US 424 (1971).

138 See 29 CFR $\$ \$ 1604,1605$.

134401 US 424 (1971).

135 Id at $426-34$.

136 The EEOC did not directly interpret Section 703(a). But the Court's interpretation of discrimination in Section 703(a) establishing a disparate impact standard did draw on the agency's construction of 'Title VII even though the Court never explicitly gave deference to this EEOC construction. See id at 431-32.
} 
deference" and upheld the EEOC's interpretation, concluding that it "express[ed] the will of Congress." 137

In a second early Title VII case, Espinoza $v$ Farah Manufacturing Co, ${ }^{138}$ the Court addressed the question under Title VII of whether discrimination on the basis of "national origin" encompassed discrimination on the basis of citizenship status. ${ }^{139}$ In an interpretive guideline, the EEOC explained that it did. ${ }^{140}$ 'The Court, citing to Griggs, explained that the EEOC's interpretation of the statute is "no doubt entitled to great deference" but concluded that the "application of the guideline would be inconsistent with an obvious congressional intent not to reach the employment practice in question." 141

In a third early Title VII case, Albermarle Paper Co $v$ Moody, ${ }^{142}$ the Court again gave "great deference" to the EEOC's interpretation of the job-relatedness requirement for employment tests. ${ }^{143}$ But in the case, the judicial application of the great deference standard to EEOC interpretive guidelines received its first challenge as Justices Burger and Blackmun argued that the Court did not owe the agency interpretation such deference. ${ }^{144}$ The justices reasoned that because the agency lacked the authority to issue the guidelines and the guidelines had not been subjected to notice-and-comment procedures, a lesser form of deference should apply instead. ${ }^{145}$ Justice Stewart, writing for the majority, responded simply by quoting Justice Burger's unanimous opinion in Griggs: the EEOC's guidelines were entitled to "great deference" because they constituted "the

\footnotetext{
137 Id at 433-36 (examining the legislative history of Title VII and finding that the guidelines' requirement that employment tests be job related is consistent with the intent of Congress).

138414 US 86 (1973).

139 See id at 87. Section 703(a) prohibits employment discrimination on the basis of "race, color, religion, sex, or national origin." See 42 USC $\$ 2000$ e-2(a).

140 According to the EEOC interpretive guideline: "Because discrimination on the basis of citizenship has the effect of discriminating on the basis of national origin, a lawfully immigrated alien who is domiciled or residing in this country may not be discriminated against on the basis of his citizenship." Espinoza, 414 US at 92, quoting 29 CFR \& 1606.1 .

${ }^{141}$ Espinoza, 414 US at 94.

142422 US 405 (1975).

143 See id at 431 .

144 See id at 449 (Blackmun concurring in judgment); see id at 451-52 (Burger dissenting).

${ }^{145}$ See id at 449 (Blackmun concurring in judgment), see id at 451-52 (Burger dissenting).
} 
administrative interpretation of the Act by the enforcing agency." 146

Finally, in a fourth case decided a year after Albermarle, Justice Marshall, writing for a unanimous Court in McDonald $v$ Santa Fe Trail Transportation Co, ${ }^{147}$ gave great deference to an EEOC interpretation of Title VII as protecting white employees from discrimination. ${ }^{148}$ Justice Burger and Blackmun's decision to join the decision was mysterious given their concerns expressed in Albermarle about giving great deference to interpretations not subject to notice-and-comment procedures.

In reviewing agency interpretations of Section 5 of the Voting Rights Act in two cases decided in the early 1970s, the Court was just as consistent in giving heightened deference to the Attorney General's view of the statute. Despite the lack of explicit statutory authority to issue guidelines interpreting the ambiguities in Section 5, the Attorney General promulgated guidelines interpreting Section 5 in 1971 and also expressed his view about the meaning of the statutory provision in testimony before Congress during the 1970 and 1975 re-authorizations of the statute. The Court gave heightened deference to each of these interpretations of the Act.

In Perkins $v$ Matthews, ${ }^{149}$ the Court addressed whether changes in the location of polling places and city boundaries were "voting changes" that required the Attorney General's preclearance under Section 5 of the VRA. ${ }^{150}$ The Court determined that the two changes did affect voting and then cited the Attorney General's testimony before Congress that the changes required preclearance. ${ }^{151}$ Quoting Udall, the Court

146 Espinoza, 414 US at 431.

147427 US 273 (1976).

148 See id at 279 . The requirement that statutes apply to all classes within the statutory classification had long been settled under the Equal Protection Clause and was not considered controversial by even the more liberal justices. See, for example, Yick Wo $v$ Hopkins, 118 US 356,369 (1886) ("E]qual protection of the laws is a pledge of the protection of equal laws.").

149400 US 379 (1971).

150 See id at 382 .

151 In this testimony during the 1970 reauthorization of the Voting Rights Act, the Attorney General explained that the "Department [of Justice] regarded relocating polling places and annexing territory as falling within the Act." To support this testimony, the Department of Justice presented evidence that prior jurisdictions submitted similar changes, which demonstrated that the Attorney General's interpretation was already accepted by at least some of the covered jurisdictions. Id at 391-92. 
concluded that "th[is] interpretation given the statute by the officers or agency charged with its administration" was entitled to "great deference." 152 In Georgia v United States, ${ }^{153}$ the Court was less explicit in its application of the "great deference" framework, but no less deferential to the Attorney General's interpretation. ${ }^{154}$ In interpretive guidelines titled "Procedures for the Administration of Section 5," the Attorney General published rules for voting change submissions and objections. These rules required, inter alia, the Attorney General to object to voting changes within sixty days and placed the burden on the submitting party to prove that the voting change did not violate the Act. ${ }^{155}$ Using the language of heightened deference, the Court held that the Attorney General's "choice of proof standards" was "reasonable" and "consistent with the Act." 156

In neither case did the Court mention the fact that the agency did not promulgate its interpretations through the more formalized notice-and-comment procedures. This omission suggests that the form of the agency interpretation was not relevant to the Court's deference choice.

Finally, in this period, the Court also appeared to give heightened deference to HEW's interpretation of 'Title VI of the Civil Rights Act. In Lau v Nichols, ${ }^{157}$ the question raised was the validity under Title VI of a school district's decision to deny language instruction to students who lacked English-speaking skills. ${ }^{158}$ As in the Title VII and VRA cases, the agency interpretations that the Court reviewed were in the form of an interpretive guideline issued by HEW. ${ }^{159}$ These guidelines prohibited the disbursement of federal funding to schools that

\footnotetext{
152 Id at 391 (citation and quotation marks omitted).

153411 US 526 (1973).

154 See id at $538-39$.

155 Id at 536-37. The Court conceded that Section 5 did not authorize the Attorney General to promulgate any regulations, but found questionable authority for the issuance of the interpretive guidelines in a section of the United States Code on Government Organization and Employees. Id at 536 (contending that 5 USC $\$ 301$, which gives to '[t]he head of an Executive department' the power to 'prescribe regulations for the government of his department, ... [and] the distribution and performance of its business ..., is surely ample legislative authority for the regulations").

156 Id at 538-39.

157414 US 563 (1974).

158 See id at 566.

159 See id at $566-67$.
} 
deny educational opportunities to persons on the basis of national origin or due to language deficiencies. ${ }^{160}$ The guidelines required schools to take "affirmative steps to rectify the language deficiency in order to open its instructional program to these students." ${ }^{161}$ Perhaps most controversially, the HEW guidelines also prohibited the utilization of criteria or methods of administration "which have the effect of subjecting individuals to discrimination" or have "the effect of defeating or substantially impairing accomplishments of the objectives of the program as respect individuals of a particular race, color, or national origin." 162

For the majority, the case was less about what deference was owed to the interpretive guidelines and more about whether the federal government had the authority to act in accordance with the guidelines. ${ }^{163}$ The Court simply held that the federal government did not exceed the limits of its authority in establishing conditions for the disbursement of money to schools. ${ }^{164}$ But for those in concurrence, which included Justices Burger and Blackmun, the guidelines were valid because they were "reasonably related to the purposes of the enabling legislation." 165 'The Department's consistent construction of the statute to require "affirmative remedial efforts to give special attention to linguistically deprived children" was therefore "entitled to great weight." 166

In sum, the Court in the early Civil Rights Act and VRA cases consistently granted heightened deference to agency interpretations of these statutes. The Court applied this heightened deference even though the agency interpretations were in the form of interpretative guidelines that lacked binding legal effect and none of the agencies had been affirmatively

\footnotetext{
160 See id at $567-568$ (describing the series of interpretive guidelines adopted by HEW).

${ }_{161}$ Lau, 414 US at 568, quoting Department of Health and Human Services, Notice, 35 Fed Reg 11595 (1970).

162 Id, quoting $45 \mathrm{CFR} \S 80.3(\mathrm{~b})(2)$.

${ }_{163}$ Nowhere in the case does the Court cite to cases relying on the "great deference" standard or the lesser Skidmore deference.

164 Lau, 414 US at 569.

165 Id at 571 (Blackmun concurring).

166 Id. HEW's interpretation of Title VI can be seen as raising a constitutional issue since it addressed the validity of a national origins classification, but the justices in concurrence did not seem to view the interpretation in that light as they did not discuss the Fourteenth Amendment or any cases addressed under it.
} 
authorized to issue such guidelines. With the exception of two justices dissenting in the Title VII case of Albermarle, the deference dichotomy was irrelevant. The clear message from the Court was that the agencies controlled the meaning of the civil rights statutes and the judicial role was limited to ensuring that in these cases the administrative interpretations were consistent with congressional intent. The Court never asserted its authority to independently judge the meaning of statutes in the context of competing agency interpretations. In the next section I argue that when the Court turned to more constitutionally charged and controversial questions of statutory interpretation, there was a marked shift in its deference doctrine.

b) The revival of Skidmore. Prior to the Court's Title VII decision in General Electric Co $v$ Gilbert, the Skidmore deference doctrine appeared dead. Only in rare cases did the Court apply the doctrine, none of which involved civil rights statutes. ${ }^{167}$ In fact, during the very term that the Court revived Skidmore deference in Gilbert, it applied "great deference" in another case involving an agency interpretation of Title VII. However, once revived in Gilbert, Skidmore deference would be more regularly applied in the Court's review of agency interpretations of civil rights statutes. Thus far, scholars have failed to satisfactorily identify the reason for this Skidmore revival.

The Court's revival of Skidmore deference in Gilbert is easier to understand once we examine the constitutional context surrounding the case-in particular, a related constitutional case decided two years before Gilbert, Geduldig $v$ Aiello. ${ }^{168}$ In Geduldig, a conservative majority of the Court held that the exclusion of pregnant women from a state disability insurance program did not constitute an impermissible gender classification under the Equal Protection Clause. ${ }^{169}$ Reasoning

\footnotetext{
167 See note 49 (citing the four cases between the late 1940s and Gilbert in which the Court applied Skidmore deference).

168417 US 484 (1974).

169 See id at 497. Geduldig was decided at a time when equal protection doctrine related to gender classifications was very much in flux. The Supreme Court was divided on whether gender was a suspect classification entitled to strict scrutiny. See generally Frontiero $v$ Richardson, 411 US 677 (1973). The Court ultimately settled on the finding that gender was a quasi-suspect classification entitled to intermediate scrutiny. See Craig v Boren, 429 US 190, 197-98 (1976) (announcing the intermediate scrutiny standard for gender classifications).
} 
that "[t]here is no risk from which men are protected and women are not," the Court concluded that there was no evidence from the record that the selection of risk covered in the insurance program "worked to discriminate against any definable group or class." 170 Since the law did not classify, the majority proceeded to uphold the law under a very lenient form of rational basis review. ${ }^{171}$

Two years later, the Court in Gilbert addressed whether a similar pregnancy exclusion from a disability plan violated Title VII of the Civil Rights Act. ${ }^{172}$ In an interpretive guideline, the EEOC construed the Title VII prohibition on sex discrimination to encompass "disparate treatment of pregnancy disabilities in the employment context." 173 According to its jurisprudence of the prior six years, the Court should have deferred to the EEOC as the primary interpreter of the statute, but the Court in Gilbert took a different path.

Although Gilbert raised an issue of statutory interpretation, the Court made immediately apparent the influence that the constitutional decision in Geduldig would have on its interpretation of Title VII. The Gilbert majority announced early in the opinion:

While there is no necessary inference that Congress, in choosing [the language of Section 703(a)(1)], intended to incorporate into Title VII the concepts of discrimination which have evolved from court decisions construing the Equal Protection Clause of the Fourteenth Amendment,

\footnotetext{
170 Geduldig, 417 US at 496-97.

171 See id at 495.

172 See Gilbert, 429 US at 127.

173 The EEOC interpretive guideline stated:
}

Disabilities caused or contributed to by pregnancy ... are, for all job-related purposes, temporary disabilities and should be treated as such under any health or temporary disability insurance or sick leave plan available in connection with employment. Written and unwritten employment policies and practices ... shall be applied to disability due to pregnancy or childbirth on the same terms and conditions as they are applied to other temporary disabilities.

29 CFR $\$ 1604.10$ (b). Since the prohibition on sex discrimination was inserted into the House version of the civil rights bill at the last minute and was subject to limited debate in the Senate, many of the ambiguities in its application remained. See Robert Stevens Miller Jr, Sex Discrimination and Title VII of the Civil Rights Act of 1964, 51 Minn L Rev 877, 879-83 (1966) (describing the legislative consideration of the sex discrimination provision under Title VII). 
the similarities between the congressional language and some of those decisions surely indicate that the latter are a useful starting point in interpreting the former. ${ }^{174}$

The Court explained that its constitutional jurisprudence was particularly relevant since Congress failed to define the term "discrimination." 175 Given this statutory ambiguity, equal protection cases "afford an existing body of law analyzing and discussing that term in a legal context not wholly dissimilar to the concerns which Congress manifested in enacting Title VII." 176 Analogizing from the meaning of "discrimination" articulated in Geduldig, the majority concluded that the pregnancy exclusions from the disability plan did not constitute sex discrimination under Title VII. ${ }^{177}$

To justify its exercise of control over the meaning of the statute, the Court reasoned, as the two Albemarle dissenters had, that the EEOC's interpretation was not entitled to great deference because the interpretive guidelines lacked the force of law. ${ }^{178}$ Rather than being entitled to great deference, the Court, citing Skidmore, explained that the interpretive guidelines would only receive the weight that accorded with their persuasiveness. ${ }^{179}$ The Court found the guidelines unpersuasive and adopted the interpretation of sex discrimination it had established in its constitutional jurisprudence. ${ }^{180}$

174 Gilbert, 429 US at 133.

175 See id.

176 Id. The Court therefore determined that the "decision in Geduldig v Aiello,... dealing with a strikingly similar disability plan, is quite relevant in determining whether or not the pregnancy exclusion did discriminate on the basis of sex." Id.

177 See id at 134-36.

178 See Gilbert, 429 US at 141. The Court explained that the evaluation of the interpretations entitlement to "great deference" must be evaluated on the basis of the recognition that "in enacting Title VII, [Congress] did not confer upon the EEOC authority to promulgate rules or regulations pursuant to that Title." Courts, therefore, "may accord less weight to ... guidelines than to administrative regulations which Congress has declared shall have the force of law." Id.

179 Id at $141-42$.

180 Id at 145. The Court proceeded to find that the interpretation contained in the guidelines were not persuasive because the EEOC did not consistently apply it. Id at 142. This may have been an appropriate basis for finding that the interpretation failed the Skidmore deference standard, but it was mere pretext for applying Skidmore in the first place. In subsequent pre-Chevron cases, the Court gave no deference to EEOC interpretations of Title VII despite the lack of any evidence that the agency's interpretation was inconsistent with a prior one. See, for example, Trans World Airlines, Inc v Hardison, 432 US 63, 77 (1977) (finding that an EEOC guideline interpreting the religious accommodations requirement under Section $703(\mathrm{a})(1)$ did not provide any 
Justices Brennan and Marshall denounced the majority for abandoning the "great deference" standard that had been consistently applied to the Commission's guidelines in prior cases. ${ }^{181}$ The justices argued that Congress left to the EEOC the complex economic and social inquiries that go into determining the meaning of discrimination in the employment context and that the Court should have recognized "the unique persuasiveness of EEOC interpretations in the area." 182

In Gilbert, the justices clearly considered the "great deference" and Skidmore deference standards to be distinct. The application of Skidmore deference in Gilbert represented a rejection of agency primacy in the determination of statutory meaning. Instead, the Court elevated itself into the dominant interpretive role by granting itself the highly discretionary authority of deciding whether an agency's interpretation is persuasive.

The Court's abandonment of "great deference" in Gilbert was not an isolated incident. That same year, the Court in Beer $v$ United States ${ }^{183}$ declined to give any deference to the Attorney General's interpretation of Section 5 of the VRA, an interpretation that also implicated an ongoing constitutional controversy. ${ }^{184}$ Beer raised the question of the meaning of discriminatory "effect" under the statute. ${ }^{185}$ Although the Court held in Griggs that the Title VII prohibition on discrimination encompassed a discriminatory-effects standard, ${ }^{186}$ the Court, by the time it decided Beer, was in the process of rejecting that standard as a basis for proving a constitutional violation under the Equal Protection Clause. The Court in Washington $v$ Davis ${ }^{187}$ held that in only the rarest of cases would proof of discriminatory impact alone be a sufficient basis for an equal

guidance); International Brotherhood of Teamsters v United States, 431 US 324, 369 (1977) (refusing to defer to an EEOC interpretation of Section 703(h) prohibiting a seniority system that "locked minority workers into inferior jobs and perpetuated prior discrimination").

181 Gilbert, 429 US at 155-56 (Brennan concurring and dissenting), citing Albemarle Paper Co, 422 US at 431; Griggs, 401 US at 433-34; Phillips v Martin Marietta Corp, 400 US 542, 545 (1971) (Marshall concurring).

182 Gilbert, 429 US at 155-56 (Brennan concurring and dissenting)

$183 \quad 425$ US 130 (1976).

184 See id.

185 See id at $135-41$.

186 See Griggs, 401 US at 431-32.

187 426 US 229 (1976). 
protection violation. ${ }^{188}$ A challenger to a state action under the Equal Protection Clause would instead have to prove that the state's act was motivated by a discriminatory purpose. ${ }^{189}$ One major reason for the Court's rejection of a constitutional discriminatory effect standard was its potential intrusion on state authority. ${ }^{190}$ The Court's refusal to defer to the Attorney General's more expansive interpretation of discriminatory effect under Section 5 in Beer can be seen as a response to this constitutional concern with effects-based standards for judging discrimination.

Section 5 of the VRA not only included an explicit discriminatory effects standard, but also placed the burden on the covered jurisdiction to prove that its voting change would not have such an effect. ${ }^{191}$ The Court in Beer addressed the question of the proper baseline for measuring discriminatory effect. The answer would shape how broadly the discriminatory effects standard would reach into the authority of covered states to adopt voting changes. In Beer, the Court reviewed the Attorney General's preclearance objections to the city of New Orleans's reapportionment of its city council districts. ${ }^{192}$ In the objection letters, the Attorney General appeared to rely on the Court's earlier equal protection jurisprudence in measuring discriminatory effect from the baseline of equal opportunity for members of minority groups to elect their candidate of choice. ${ }^{193}$ Under this baseline, if the reapportioned districts failed to provide racial minorities with equal opportunity to elect candidates of their choice, usually measured in terms of a proportional opportunity for minority-preferred candidates to

188 See id at 241. The Court in a series of cases establishing the discriminatory purpose standard explained, "a law's disproportionate impact is [not] irrelevant in cases involving Constitution-based claims of racial discrimination." Id. But in order for proof of a state action's disparate impact to alone be a basis for a constitutional violation, the challenger must show "a clear pattern, unexplainable on grounds other than race." Village of Arlington Heights v Metropolitan Housing Development Corp, 429 US 252, 266 (1977).

189 See Davis, 426 US at 239.

190 The Court explained that subjecting state action to a discriminatory effects standard "would be far reaching and would raise serious questions about, and perhaps invalidate, a whole range of tax, welfare, public service, regulatory, and licensing statutes." Id at 248 .

$19142 \mathrm{USC} \$ 1973 \mathrm{~b}$.

192 See Beer, 425 US at 135-36.

193 See Beer v United States, 374 F Supp 363, 369 n 26, 370 n 33 (DDC 1974) (reproducing the Attorney General's two objections to New Orleans's redistricting plans). 
win elections, the change would not be precleared. ${ }^{194}$ For southern jurisdictions like New Orleans, which at the time had never elected an African American to the city council or drawn any districts that provided minority-preferred candidates with an opportunity to win elections, ${ }^{195}$ the establishment of a baseline of equal opportunity to elect under Section 5 would force a dramatic change in their districting scheme.

The Court rejected this interpretation, declining to give any deference to the objection letters. The Court denied deference even though it had given heightened deference to the Attorney General's interpretations contained in congressional testimony and interpretive guidelines in two prior Section 5 cases. Instead, relying on a very dubious reading of the legislative history, the Court independently determined that the baseline for measuring discriminatory effect would be the prior voting scheme. ${ }^{196} \mathrm{~A}$ voting change would only be deemed to have the effect of discriminating if it "would lead to a retrogression in the position of racial minorities with respect to their effective exercise of the electoral franchise." 197 The Court's interpretation of discriminatory effect in Beer essentially returned discretion to the states in the reapportionment of electoral districts. Under the Supreme Court's interpretation, the covered jurisdiction only had to ensure that racial minorities were no worse off than before. Given the historical resistance of the covered jurisdictions to giving minorities any political power, the Court's standard gave these jurisdictions extremely broad discretion to reapportion districts how they saw fit. ${ }^{198}$

194 See id. See also id at 388 ("The value to which the New Orleans black vote is legally entitled is 'a theoretical optimum designed to give fair representation to both minority and majority groups in the City.") (citation omitted).

195 Id at $374-75$.

196 See Beer, 425 US at 141. Far from supporting a non-retrogression standard, the language in the Senate Committee in support of renewal of the Voting Rights Act in 1975 raises rather than resolves the question of the proper baseline for assessing a dilutive practice. In the report, Congress stated:

The standard [under $\$ 5$ ] can only be fully satisfied by determining on the basis of the facts found by the Attorney General [or the District Court] to be true whether the ability of minority groups to participate in the political process and to elect their candidate of choice is augmented, diminished, or not affected by the changes affecting voting.

Id, quoting HR Rep No 94-196 at 60.

197 Id.

198 One scholar described the consequences of the Court's interpretation of Section 5 
In dissent, Justices Marshall and Brennan found the majority's construction awkward and contrary to the purposes of Section 5 of the VRA. ${ }^{199}$ Interestingly, unlike in Gilbert, where the two justices vehemently opposed the Court's refusal to give "great deference" to the EEOC's interpretation of Title VII, the dissenters appeared to concede that such deference was not appropriate here. Rather, consistent with the majority's approach in Gilbert, the justices independently determined, without reference to any clear indicator of congressional intent, that the standard of proof under Section 5 is "undoubtedly tied to the standards of the Constitution." 200 The dissenters merely critiqued the majority for adopting a construction inconsistent with the constitutional standard they found appropriate for the case. ${ }^{201}$

In Regents of the University of California $v$ Bakke, ${ }^{202}$ the Court for the third time denied heightened judicial deference to agency interpretations of a civil rights statute. Bakke involved the statutory and constitutional validity of an affirmative action program to increase the enrollment of racial minorities in the University of California, Davis School of Medicine. ${ }^{203}$ From a statutory perspective, the case raised the question of the meaning of discrimination under Title VI of the Civil Rights Act, and in particular, whether UC Davis' admissions preferences for racial minorities who had experienced past societal discrimination constituted "discrimination" against whites. ${ }^{204}$

The Department of Health, Education, and Welfare had issued regulations through notice-and-comment rulemaking

in Beer as perverse; the non-retrogression standard "reward[ed] those jurisdictions with a history of the worst dilution of black electoral strength." Those jurisdictions now had free rein to install racially discriminatory voting structures so long as they were no more discriminatory than the ones that existed before. See Richard L. Engstrom, et al, Louisiana, in Chandler Davidson and Bernard Grofman, eds, Quiet Revolution in the South: The Impact of the Voting Rights Act, 1965-1990 103, 115 (1994).

199 See Beer, 425 US at 146.

200 Id at 148 . The dissenters merely cited to language in a prior opinion upholding the validity of Section 5. Id, quoting South Carolina v Katzenbach, 383 US 301, 334 (1966) ("The Act suspends new voting regulations pending scrutiny by federal authorities to determine whether their use would violate the Fifteenth Amendment.").

201 See id at $156-58$.

202438 US 265 (1978).

203 See id at $269-79$.

204 Id at 291-95 (rejecting a two-class theory in which whites would receive a different degree of protection than African Americans under the Equal Protection Clause). 
permitting such affirmative action admissions programs under Title VI. ${ }^{205}$ Justice Powell, who wrote the influential opinion in Bakke, ${ }^{206}$ ignored the agency regulation. He reasoned from a selective reading of the legislative history that the statutory standard was indistinguishable from the constitutional standard. ${ }^{207}$ According to Justice Powell, "Title VI reveals a congressional intent to halt federal funding of entities that violate a prohibition of racial discrimination similar to that of the Constitution." 208 Given the relationship between the statutory and constitutional meaning of discrimination, it was not necessary to look to the HEW regulation to address the statutory ambiguity. ${ }^{209}$ Instead, Justice Powell resolved the ambiguity about the meaning of discrimination under Title VI through an independent determination of what discrimination meant under the Constitution. ${ }^{210}$

It is perhaps not that surprising that Justice Powell, who was relatively conservative on most civil rights issues, ${ }^{211}$ did not defer to the more liberal agency interpretation of "discrimination." But the four most liberal justices in concurrence also refused to defer to the agency's interpretation of Title VI. While the concurring justices suggested that the regulations were "deserving of respect," 212 it seems clear from

205 The HEW regulation provided: "Even in the absence of such prior discrimination, a recipient in administering a program may take affirmative action to overcome the effects of conditions which resulted in limiting participation by persons of particular race, color, or national origin." Id at 344-45 (Brennan concurring in judgment and dissenting in part), quoting 45 CFR $\$ 80.3(\mathrm{~b})(6)$ (ii).

206 Although Justice Powell wrote only for himself, his opinion articulated the constitutional standard that would apply to future affirmative action cases. See Bertrall L. Ross II, Democracy and Renewed Distrust: Equal Protection and the Evolving Judicial Conception of Politics, 101 Cal L Rev 1565, 1597-1605 (2013).

207 See Bakke, 438 US at 284.

${ }^{208}$ Id. But see Abernathy, Title VI and the Constitution, 70 Georgetown L J at 25-30 (cited in note 116) (arguing that the key compromise that secured passage of Title VI was one in which the agencies were given the authority to define discrimination).

${ }^{209}$ This approach contrasted with what the Court expressed in an opinion that Justice Powell joined in $L a u$, which was to look to the HEW regulation first in ascertaining the meaning of Title VI.

210 Bakke, 438 US at 305-14 (applying the equal protection analysis to the affirmative action program). The decision to ignore the HEW regulation was particularly notable considering that, unlike the interpretive guidelines at issue in $L a u$, the affirmative action regulations in Bakke were promulgated through notice-and-comment procedures. Id at 341-43 (Brennan concurring in judgment and dissenting in part).

211 See Ian F. Henry Lopez, "A Nation of Minorities": Race, Ethnicity, and Reactionary Colorblindness, 59 Stan L Rev 985, 1034-46 (2007).

212 See Bakke, 438 US at 346 (Brennan concurring in judgment and dissenting in 
their opinion that the deference did not extend to the meaning of discrimination, which was considered a determination within the Court's constitutional domain. ${ }^{213}$ Rather, deference would be contingent on the agency's interpretation being in concert with the justices' interpretation of the Constitution. ${ }^{214}$ The liberal justices explained in agreement with Justice Powell, "Title VI prohibits only those uses of racial criteria that would violate the Fourteenth Amendment." ${ }^{215}$ If the agency's interpretation had failed to accord with the concurring justices' constitutional understanding, it is reasonable to surmise that the justices would have ignored it.

In sum, the pattern of deference to agency interpretations in the pre-Chevron era does not map on very well to the deference dichotomy or the other explanations for deference choices. The Court applied "great deference," Skidmore deference, and no deference to agencies' interpretive guidelines, regulations, and congressional testimony with few references to the principle underpinning the deference dichotomy-that only rules issued with the force of law should receive heightened deference. While the more liberal justices in Gilbert complained about the conservative majority's refusal to apply heightened deference to the more liberal agency interpretation, these justices, for the most part, went along with similar denials of heightened deference in Beer and Bakke.

Instead, what connects Gilbert, Beer, and Bakke, is the Court's consistent denial of more than minimal deference to

part).

213 This is reflected in the Court's usage of the administrative agency more to confirm its conclusion as to the meaning of discrimination, than as an authoritative interpretation to be deferred to. See id at 346-49 (Brennan concurring in judgment and dissenting in part).

214 Id at 336-37 (Brennan concurring in judgment and dissenting in part). Justice Brennan explained, "the legislative history shows that Congress specifically eschewed any static definition of discrimination in favor of broad language that could be shaped by experience, administrative necessity, and evolving judicial doctrine." Id at 337. For Justice Marshall, in concurrence, the starting point for the meaning of discrimination under Title VI was his interpretation of the meaning of the Equal Protection Clause. See id at 396-97 (Marshall concurring in judgment and dissenting in part) ("It is plain that the Fourteenth Amendment was not intended to prohibit measures designed to remedy the effects of the Nation's past treatment of Negroes.").

215 Bakke, 438 US at 328-32 (Brennan concurring in judgment and dissenting in part). The four more conservative justices-Chief Justice Burger and Justices Stevens, Stewart, and Rehnquist-argued that the affirmative action program was inconsistent with the plain language of Title VI. See id at 412-18 (Stevens concurring in judgment and dissenting in part). 
agency interpretations when they aimed to resolve questions central to ongoing constitutional controversies. The proximity of statutory questions about the meaning of discrimination and discriminatory effect to the constitutional domain appeared to have a greater influence on deference choices than both the deference dichotomy and ideology. The Court in these cases seemed to manipulate deference doctrine to resist an administrative role in making Constitution-based determinations. In the next section, I examine the post-Chevron era, which offers further support for this theory of judicial resistance to administrative constitutionalism.

3. Post-Chevron: the Court's inconsistent application of heightened deference to interpretive rules

When the Court decided Chevron in 1984, it apparently resolved the question of when agency interpretations merited heightened deference. The Chevron Court held that so long as the agency's interpretation is not contrary to the clear intent of Congress and is reasonable, courts should defer. ${ }^{216}$ As detailed in Part I, this heightened deference standard mirrored the "great deference" standard that the Court had frequently applied since the mid-1960s. ${ }^{217}$

In terms of the deference dichotomy, although the Court in Chevron reviewed an agency interpretation in the form of a legislative rule, the language in the opinion appeared to indicate that heightened deference would apply to all forms of agency interpretations. ${ }^{218}$ The Court frequently applied Chevron deference to both formal legislative rules and informal agency interpretations until the Court formally adopted the deference dichotomy in Christensen v Harris County (2000) and United States v Mead Corporation (2001). ${ }^{219}$

But the Court treated some agency interpretations in the civil rights domain differently. The Court applied minimal to no deference when reviewing the EEOC's interpretation of

216 Cheuron, 467 US at 843

217 See Part I.B.

218 See Cheuron, 467 US at 843-44 (deriving the basis for deference from a theory of implicit delegation in which statutory ambiguity is presumed to be a delegation to agencies to interpret statutes and limiting the judicial role to ensuring that the agency's interpretations are reasonable).

219 See Part I.B. 
discrimination under Title VII and the Attorney General's interpretation of discriminatory purpose under the VRA. The Court did so even while continuing to extend Chevron's reach to other interpretations by these agencies that did not implicate constitutional meaning.

Two years after Chevron, the Court in Meritor Savings Bank $v$ Vinson, ${ }^{220}$ revived Skidmore deference doctrine again in the context of its review of an EEOC interpretation of Title VII. ${ }^{221}$ Similar to Gilbert and in contrast to two other cases decided the same year in which the Court gave Chevron deference to informal agency interpretations, ${ }^{222}$ Meritor Savings implicated a statutory question of constitutional dimension. The statutory question in the case was whether sexual harassment constituted discrimination on the basis of sex-an issue that directly implicates the meaning of the prohibition on sex discrimination under the Equal Protection Clause. ${ }^{223}$ While the Court ultimately concurred with the EEOC's interpretive guidelines, it did not apply Chevron deference to the agency's interpretation of the statute. Rather, the Court cited Gilbert and quoted Skidmore for the proposition that the interpretation was "not controlling upon the courts by reason of their authority," but rather "constitute[d] a body of experience and informed judgment to which courts and litigants may properly resort for guidance." 224 In other words, the EEOC's interpretation was merely persuasive authority as to the meaning of the statute that the Court retained the discretion to take or leave.

\footnotetext{
$220 \quad 477$ US 57 (1986).

221 See id at 65.

222 In the two cases, the Court extended Chevron deference to the Federal Deposit Insurance Corporation's interpretation of the Federal Deposit Insurance Act and the Food and Drug Administration's interpretation of the Federal Food, Drug, and Cosmetic Act even though the regulations were never promulgated as regulations. See Young $v$ Community Nutrition Institute, 476 US 974, 977-81 (1986) (acknowledging that the FDA set tolerance levels for harmful substances in food through an informal process, but arguing that the agency's interpretation should nonetheless be given Cheuron deference); Federal Deposit Ins Corp v Philadelphia Gear Corp, 476 US 426, 439 (1986) ("Although the FDIC's interpretation of the relevant statute has not been reduced to a specific regulation, we conclude nevertheless that the FDIC's practice and belief [are entitled to deference under Chevron].").

223 Meritor Savings, 477 US at 59.

224 Id at 65, quoting Gilbert, 429 US at 141-42. See also Moot, 1 Admin L J at 244 (cited in note 65) (contrasting the DC Circuit's deferential review of the EEOC guidelines with the Supreme Court's more independent review of the meaning of the statute).
} 
In subsequent Title VII cases, the Court alternated between taking or leaving the EEOC's interpretation while consistently applying the lower Skidmore deference standard in many cases and no deference at all in others. ${ }^{225}$ In fact, the overwhelming majority of the cases in which the Court explicitly applied Skidmore deference between Chevron and Christensen-Mead involved questions of the meaning of civil rights statutes, Title VII of the Civil Rights Act, the Age Discrimination in Employment Act, and the Americans with Disabilities Act. ${ }^{226}$

One potential response might be that the Court refused to accord heightened deference in these cases based on its negative view of the EEOC. If the Court distrusted the EEOC or thought it lacked expertise or political accountability, the Court's decision to give minimal deference might not have been motivated by the constitutional dimensions of the interpretive questions but by concerns about the agency itself. ${ }^{227}$ This argument is weakened by two post-Chevron doctrinal developments. First, the Court in a case decided after Meritor Savings did give Chevron deference to an EEOC interpretation of Title VII. In the 1988 case of EEOC $v$ Commercial Office Products $\mathrm{Co}^{228}$ the Court addressed inter alia the statutory

225 See, for example, EEOC v Arabian American Oil Co, 499 US 244, 257-58 (1991) (applying Skidmore deference and rejecting the EEOC's interpretation of Title VII); Ansonia Board of Education v Philbrook, 479 US 60, 66-71 (1986) (applying no deference to the EEOC's interpretation of Title VII); Local 28 of the Sheet Metal Workers' International Association v EEOC, 478 US 421, 465-66 (1986) (applying no deference to the EEOC's interpretation of Title VII).

226 Of the eight cases applying Skidmore deference between Cheuron and Christensen, six of them involved judicial review of agency interpretations of civil rights statutes. See Sutton v United Airlines, 527 US 471, 502 (1999) (applying Skidmore deference in the review of the EEOC's interpretation of the ADA); Bragdon v Abbott, 524 US 624, 642 (1998) (applying Skidmore deference to the review of the EEOC's interpretation of the ADA); EEOC $v$ Arabian American Oil Co, 499 US 244, 258 (1991) (applying Skidmore deference to the review of the EEOC's interpretation of Title VII of the Civil Rights Act); Ansonia Board of Education v Philbrook, 479 US 60, 69 n 6 (1986) (applying Skidmore deference to the review of the EEOC's interpretation of Title VII of the Civil Rights Act); Local No 93, International Association of Firefighters, AFL-CIOv Cleveland, 478 US 501, 518 (1986) (applying Skidmore deference to the EEOC's interpretation of Title VII of the Civil Rights Act); Meritor Savings, 477 US at 65 (applying Skidmore deference to the EEOC's interpretation of Title VII of the Civil Rights Act). For cases applying Skidmore that did not involve judicial review of agency interpretations of civil rights statutes, see Metropolitan Stevedore Co v Rambo, 521 US 121, 136 (1997); Martin v Occupational Safety and Health Review Commission, 499 US 144, 157 (1991).

227 See, for example, Hart, 74 Fordham L Rev at 1949-51 (cited in note 102); Wern, 60 Ohio St L J at 1578-80 (cited in note 102).

228486 US 107 (1988). 
question of what it meant, for purposes of determining whether a charge has been timely filed under Title VII, to "terminate" an agency proceeding. ${ }^{229}$ Ignoring the deference standard applied in Meritor Savings, a majority of the Court agreed that the EEOC interpretation was entitled to Chevron deference. Justice Marshall writing for a plurality of four justices conceded that the EEOC's interpretation of "terminate" may not have represented the most natural or frequent usage of the word. ${ }^{230}$ "But it is axiomatic that the EEOC's interpretation of Title VII, for which it has primary enforcement responsibility, need not be the best one by grammatical or any other standards. Rather, the EEOC interpretation of ambiguous language need only be reasonable to be entitled to deference." 231 Justice O'Connor concurring in part and concurring in the judgment agreed with the plurality's application of Chevron explaining, "sufficient ambiguity exists to warrant deference to the agency's construction of the word 'terminated." 232

It is also unlikely that the Court's distrust of the EEOC drove its denial of deference because the Court also selectively refused to defer to the Attorney General's interpretations of the Voting Rights Act when they implicated constitutional controversies. For issues that did not implicate constitutional questions, the Court gave heightened deference-for example to the Attorney General's determination of what voting changes were covered by Section 5 of the VRA. ${ }^{233}$

\footnotetext{
229 See id at 109-10.

230 See id at 115 .

231 Id.

${ }^{232}$ Commercial Office Products, 486 US at 125 (O'Connor concurring). A proponent of the "deference dichotomy" might point out that Meritor Savings involved an interpretive rule while Commercial Office Products involved a legislative rule. See 42 USC $\$ 2000 \mathrm{e}-12$ (a) (giving the EEOC the authority to promulgate procedural regulations pursuant to notice-and-comment rulemaking). Yet, the Court never mentioned this fact about the form of the agency action in its decision to grant Chevron deference in Commercial Office Products. Rather, Justice O'Connor in her concurrence offered the closest thing to an explanation for the application of Chevron in Commercial Office Products, suggesting, "deference is particularly appropriate on this type of technical issue of agency procedure." Commercial Office Products, 486 US at 125 (O'Connor concurring). O'Connor's explanation rested more on the substance of the agency interpretation rather than its form or source. Id.

${ }^{233}$ Through informal agency actions, the Attorney General interpreted Section 5 to include changes to election dates in covered jurisdictions within the category of voting changes requiring preclearance. See National Association for the Advancement of Colored People v Hampton County Election Commission, 470 US 166, 178-79 (1985); annexation of vacant land, City of Pleasant Grove v United States, 479 US 462, 467-68 (1987);
} 
But when it came to statutory questions under Section 5 of the VRA raising constitutional issues, the Court refused to apply heightened deference to the Attorney General's interpretation. For example, in a series of three cases decided between 1995 and 2000, the Court denied heightened deference to the Attorney General's interpretation of discriminatory purpose under Section 5 each time.

In the early $1980 \mathrm{~s}$, the Attorney General issued an interpretive guideline construing the Section 5 prohibition on covered jurisdictions adopting voting changes that had a discriminatory purpose. The guideline required covered jurisdictions to prove that any voting change would not violate Section 2 of the VRA in that it would not deprive minorities of an equal opportunity to elect candidates of their choice. ${ }^{234}$ In Miller $v$ Johnson, ${ }^{235}$ the Court began to chip away at this expansive interpretation of discriminatory purpose, revealing along the way its resistance to administrative constitutionalism. ${ }^{236}$ In Miller, the Court considered whether the Justice Department's interpretation of Section 5 of the VRA was a sufficient basis for a district to draw predominantly race-based electoral districts. ${ }^{237}$ The Court refused to provide heightened

changes to a political body's decision-making authority, Presley $v$ Etowah County Commission, 502 US 491, 508-09 (1992); and a political party's addition of a candidate registration fee, Morse v Republican Party of Virginia, 517 US 186, 190, 200-01 (1996). The Court did not uphold all of these interpretations, but it did consistently apply a heightened deference framework distinct from Skidmore deference. See City of Pleasant Grove, 479 US at 468 (applying "great deference"); NAACP, 470 US at 178-79 (same); Morse, 517 US at 200-01 (applying heightened deference standard applicable to agency interpretation of its own regulations); Presley, 502 US at 508 (applying Chevron deference). An argument could be raised that the Attorney General's broad interpretations of Section 5 to include many voting changes not foreseen by Congress implicated constitutional federalism concerns. Such granting of heightened deference should therefore be considered inconsistent with a theory of judicial resistance to administrative constitutionalism. But it is important to note that at the time the Court deferred to the Attorney General's interpretations in these Section 5 cases, the Court deemed the federalism boundaries to be judicially unenforceable. Instead, according to the Court, the "internal safeguards of the political process," provided protection for state authority against unduly burdensome federal actions. Garcia $v$ San Antonio Metropolitan Transit Authority, 469 US 528, 556 (1985). These VRA cases may, therefore, have raised issues of a constitutional dimension, but they did not implicate ongoing constitutional controversies being decided by the Court.

${ }_{234}$ See United States Department of Justice, Revision of Procedures for the Administration of Section 5 of the Voting Rights Act of 1965, 52 Fed Reg 486, 486-501 (1987).

235515 US 900 (1995).

${ }_{236}$ See id at 923.

237 See id at 922 . 
deference, explaining "[w]ere we to accept the Justice Department's objection [to the voting change] itself as a compelling interest adequate to insulate racial districting from constitutional review, we would be surrendering to the Executive Branch our role in enforcing constitutional limits on race-based official action." 238 In other words, it was for the Court, not the agencies, to decide the permissibility of racebased actions under the Constitution. Because of the need to avoid the serious constitutional question raised, the Court explained that the heightened deference ordinarily given to the Attorney General's interpretation of Section 5 in prior cases was not appropriate in Miller. 239

In a case decided two years later, Reno $v$ Bossier Parish School District I, ${ }^{240}$ the Court started to directly address the meaning of discriminatory purpose under Section 5-an interpretive question of continuing import in the Court's constitutional jurisprudence. ${ }^{241}$ The question raised in Bossier Parish I was whether Section 5 requires the Attorney General to deny preclearance when the voting change violates Section 2 of the VRA. ${ }^{242}$ In its guidelines, the Justice Department had interpreted Section 5 to deny preclearance in those circumstances. The Court again acknowledged that Chevron deference was normally accorded to the Attorney General's interpretation of Section 5 of the VRA, but it avoided giving such deference by citing a presumption about congressional intent. Despite a footnote in the Senate report suggesting that Congress did intend to incorporate the Section 2 standard into Section 5 , the Court expressed "doubt that Congress would depart from the settled interpretation of $\S 5$ and impose a demonstrably greater burden on the jurisdictions covered by $\$ 5 \ldots$ by dropping a footnote in a Senate report instead of amending the statute itself." 243

\footnotetext{
238 Id at 923.

239 Miller, 515 US at 923 .

$240 \quad 520$ US 471 (1997).

241 See id at 474 . In the 1980 s and $1990 \mathrm{~s}$, the Court continued to address cases about the standard of proof necessary to prove an equal protection violation. See, for example, Lewis v Casey, 518 US 343 (1996); Hernandez v New York, 500 US 352 (1991); McCleskey v Kemp, 481 US 279 (1987); Batson v Kentucky, 476 US 79 (1986).

${ }^{242}$ See id.

243 Id at 484.
} 
Finally, in the 2000 case of Reno $v$ Bossier Parish School Board $I I,{ }^{244}$ the Court again refused to apply heightened deference to the Attorney General's interpretation of Section $5 .{ }^{245}$ The case directly raised the question of the meaning of discriminatory purpose under Section 5. ${ }^{246}$ Rather than look to the agency's consistent interpretation of discriminatory purpose for guidance, ${ }^{247}$ the Court instead analogized to its own past interpretation of discriminatory effect in Beer. ${ }^{248}$ The Court explained that the discriminatory purpose prong of Section 5 must incorporate the same baseline applicable to the discriminatory effect standard announced in Beer. Since the Court had held the statutory prohibition on discriminatory effect referred only to retrogressive effect in Beer, the statutory prohibition on discriminatory purpose must refer only to retrogressive purpose. ${ }^{249}$ The Court adopted this interpretation despite clear congressional efforts to overrule the nonretrogression standard when it reauthorized Section 5 of the VRA in 1982. The Court also acknowledged that its interpretation would make the purpose prong of Section 5 essentially redundant to the effects prong as it would only punish the incompetent legislator who intended to adopt a retrogressive voting change but was not able to do so. ${ }^{250}$

Thus, as it did in the pre-Chevron era, the Court in its review of agency interpretations of Title VII of the Civil Rights Act and Section 5 of the VRA gave heightened deference to some interpretive rules and not others. This pattern conflicted with the deference dichotomy. In addition, even though the agencies' interpretations seemed to accord with the views of the more

\footnotetext{
244528 US $320(2000)$.

245 See id at 329-31.

246 See id at 322-23.

247 According to the Attorney General's interpretation of discriminatory purpose, covered jurisdictions were required to prove that the voting change would provide racial minorities with an equal opportunity to elect candidates of their choice. See United States Department of Justice, Revision of Procedures for the Administration of Section 5 of the Voting Rights Act of 1965, 52 Fed Reg 486, 486-501 (1987).

248 Board Parish II, 528 US at 329-31.

249 See id. In dissent, Justice Souter colorfully argued, "if today's decision achieves a symmetry with Beer, the achievement is merely one of well-matched error." Id at 342 (Souter concurring in part and dissenting in part).

${ }^{250}$ Id at 332 (acknowledging the limited reach of the purpose prong under the interpretation so that it only prohibits voting changes that have a non-retrogressive
} purpose). 
liberal justices, these justices only once argued for the application of heightened deference. ${ }^{251}$ Finally, the justices' inconsistency in the application of heightened deference to the agency interpretations of Title VII and the VRA suggest that the justices did not consider the general competency of the agencies and the complexity of the statutes to be factors in their deference choice. Instead, a consistent feature of the interpretive rules for which the Court denied deference is that they implicated questions that were the subject of ongoing controversies in the Court about the meaning of the Equal Protection Clause.

The Court's tendency to refuse to defer to administrative constitutionalism continued in the Mead era when the Court established doctrinally the deference dichotomy in case law. In this era, the Court continued to deny heightened deference to agency interpretations of civil rights statutes, even those in the form of legislative rules, when they implicated judicially enforceable constitutional issues. The Court did so through a process of Cheuron avoidance.

4. The Mead era: Chevron avoidance and the ADA and ADEA.

In the most recent set of cases, the Court has refused to defer to agency interpretations of the Age Discrimination in Employment Act (ADEA) and the Americans with Disabilities Act (ADA). These cases are interesting because they span the periods both before and after the Court's enshrinement of the deference dichotomy into doctrine in Christensen and Mead. And yet the Court, in its review of legislative rules during both periods, never applied heightened Chevron deference to agency interpretations that addressed questions of a constitutional dimension. The Court, however, did apply heightened Chevron

251 In Meritor Savings, four liberal justices in dissent argued that the EEOC interpretive guidelines were entitled to great deference. Meritor Savings Bank v. Vinson, 477 US at 74 (Marshall J, dissenting). However, in two other Title VII cases implicating constitutional issues, the liberal justices did not argue for the application of heightened deference to the EEOC's interpretations. See Ansonia, 479 US at 66-71 (ignoring the agency interpretation in a case addressing the requirements of religious accommodations under Title VII); Local 28, 478 US at 465-66 (acknowledging and agreeing with a contemporaneous EEOC interpretation making "race-conscious remedies for unlawful discrimination ... available" but failing to explicitly give deference to it). 
deference to such rules when the agency's interpretation did not implicate a constitutional controversy.

The Court maintained the illusion of a deference dichotomy in these cases by avoiding an express choice of deference doctrines. In isolation, these Chevron avoidance moves are questionable, but mostly unremarkable. But these decisions examined collectively show a clear pattern of Supreme Court resistance to administrative constitutionalism. In this section, I examine ADEA and ADA cases, after first briefly describing these two younger siblings to the Civil Rights Act.

The Age Discrimination in Employment Act of $1967^{252}$ makes it unlawful for employers, employment agencies, and labor organizations "to fail or refuse to hire or to discharge any individual or otherwise discriminate against any individual with respect to his compensation, terms, conditions, or privileges of employment, because of such individual's age." ${ }^{253}$ Like the Civil Rights Act, the statute lacks any detailed definition of the meaning of discrimination. As originally enacted, the Department of Labor had the authority to enforce the Act by bringing suits on behalf of individual claimants in court and promulgating regulations through notice-and-comment procedures. A reorganization of the executive branch in 1978 transferred this enforcement authority to the EEOC. ${ }^{254}$ The EEOC was given the same authority to enforce the Act through both interpretive and legislative rules.

The Americans with Disabilities Act of 1990 prohibits disability discrimination in employment, ${ }^{255}$ access to public services, ${ }^{256}$ and public accommodations. ${ }^{257}$ Multiple agencies are involved in the enforcement of the Act, with the EEOC responsible for the employment title and the Department of Justice and Transportation responsible for the public services and public accommodations titles. ${ }^{258}$ Congress gave the agencies

\footnotetext{
252 Age Discrimination in Employment Act of 1967, Pub L No 90-202, 81 Stat 602, codified at 29 USC $\$ \S 621-34$

2633 USC $\$ 623(\mathrm{a})(1)$.

2543 CFR $\$ 321$. See also 29 USC $\$ 628$ ("[T]he Equal Employment Opportunity Commission may issue such rules and regulations as it may consider necessary or appropriate for [enforcing the Act].").

25542 USC $\$ 12112$.

25642 USC $\$ 12132$.

25742 USC $\$ \$ 12182-84$.

25842 USC $\S 12116-17$ (granting the EEOC authority to issue regulations to
} 
authority to enforce their assigned provisions through the issuance of legislative and interpretive rules. ${ }^{259}$

Under the ADEA and the ADA, controversies continued about the meaning of discrimination. In age and disability cases decided both pre- and post-Mead involving judicial review of legislative rules, the Court declined to give Chevron deference to administrative interpretations of discrimination. In Olmstead $v$ $L C$, by Zimring, ${ }^{260}$ a pre-Mead case reviewing the Attorney General's interpretation of discrimination under the ADA, the Court simply stated that it "need not inquire" into whether the regulations were entitled to Chevron deference. ${ }^{261}$ The majority instead applied Skidmore deference and found the regulations persuasive under that standard. ${ }^{262}$ The rest of the justices declined to give any deference in deciding the meaning of discrimination under the statute. ${ }^{263}$

In Smith $v$ City of Jackson, ${ }^{264}$ a post-Mead case addressing the meaning of discrimination under the ADEA, ${ }^{265}$ nearly every justice refused to give Chevron deference to the EEOC interpretation of discrimination, which authorized disparate impact claims, even though the interpretation was in the form of a legislative rule. ${ }^{266}$ Justice Stevens writing for a plurality of the Court simply looked to the regulation as support for his

enforce the employment title); 42 USC $\$ \S 12134,12149,12164,12186,12188$ (granting the Attorney General and the Department of Transportation Authority to issue regulations to enforce the public services and public accommodations titles).

259 See provisions cited in note 258 .

260527 US 581 (1999).

261 Olmsteadv LC, by Zimring, 527 US 581, 598 (1999).

262 See id.

263 Id at 611-613 (Kennedy concurring) (engaging in an independent determination of the meaning of discrimination under the $\mathrm{ADA}$ and relying on the regulations as mere supporting evidence for this determination); id at 618-19 (Thomas dissenting) (looking to the Court's prior interpretations of discrimination under other civil rights statutes rather than to the regulations). In fact, Justice Thomas explained in a dissent joined by Justices Rehnquist and Scalia that, given his independent judgment about the meaning of discrimination, there was no need to even "review the integration regulation promulgated by the Attorney General." Id at $622 \mathrm{n} 5$. The justice does suggest that a heightened deference framework would have applied if the agency interpretation accorded with his judgment about the meaning of discrimination, but that would have been a rather empty form of deference.

264544 US 228 (2005).

265 See generally, id.

266 Seven of the nine justices refused to give deference to the agency's interpretation, even though four of the justices agreed with the agency's interpretation. See id at 239 (Stevens joined by Souter, Ginsburg, and Breyer); id at 263 (O'Connor joined by Kennedy and Thomas). 
independent interpretation of the statute. ${ }^{267}$ Justice O'Connor, writing for two other concurring justices, did not rely on the regulation at all, suggesting that the regulation did not interpret the statute to authorize disparate impact claims. ${ }^{268}$ Justice Scalia stood alone in arguing that Chevron deference should apply, pointing to the fact that the legally binding regulations represented the authoritative views of the agency responsible for administering the statute. ${ }^{269}$

Along with disputes about the meaning of discrimination, there were recurring questions concerning who fell within the category of protected classes under the ADA and ADEA. Did the ADEA bar discrimination against workers over forty, if it was in favor of even older workers? Were persons with HIV or bad eyesight entitled to protection as disabled persons under the ADA? Like the meaning of discrimination, delineating which classes of individuals are entitled to special legal protections has been central to judicial interpretations of the Equal Protection Clause. Under the equal protection tiers of scrutiny framework, the Court has more closely scrutinized laws that harm classes of individuals bearing immutable qualities who are politically powerless and have suffered from a history of discrimination. ${ }^{270}$ In the Court's constitutional terminology, these categories of individuals are considered discrete and insular minorities or members of a suspect class. ${ }^{271}$

When Congress adopts statutes that protect particular classes of individuals from discrimination, it is making a quasiconstitutional claim about the suspect nature of the classification. The congressional decision to protect the aged and disabled is in some tension with the Court's equal protection jurisprudence. Nine years after Congress determined that the aged were entitled to special statutory protection from discrimination under the ADEA, the Court held that the aged were not a suspect class for purposes of heightened scrutiny

\footnotetext{
267 See id at 239.

268 See Smith, 544 US at 263 (O'Connor concurring in judgment).

269 Id at 243-44 (Scalia concurring).

270 See, for example, J. Harvie Wilkinson III, The Supreme Court, the Equal Protection Clause and the Three Faces of Constitutional Equality, 61 Va L Rev 945, 97880 (1975) (linking Carolene Products footnote four to the Supreme Court's equal protection suspect class analysis).

${ }^{271}$ See id.
} 
under the Equal Protection Clause.272 Eleven years after Congress resolved to give special statutory protection to the disabled in the Rehabilitation Act of 1973 (a predecessor to the ADA), ${ }^{273}$ the Court denied suspect status under the Constitution to the disabled. ${ }^{274}$ Congress, then in turn, indirectly repudiated that judicial determination five years later by giving the disabled more protections under the ADA. In fact, using the Court's own constitutional terminology, Congress in its legislative findings supporting the ADA declared the forty-three million disabled persons protected by the Act to be discrete and insular minorities. ${ }^{275}$

In response to these congressional exercises of constitutional authority, the Court has manipulated deference doctrine to secure greater control over determinations about who is suspect and entitled to special legal protections. In particular, the Court has denied Chevron deference to agency interpretations about who is entitled to statutory protections under the ADEA and ADA.

The Court first addressed a statutory question about the meaning of disability under the ADA in the 1998 case of Bragdon v Abbott. ${ }^{276}$ The specific question was whether a person infected with the human immunodeficiency virus (HIV) was disabled and therefore entitled to protections against discrimination under the Act. 277 As the Court noted, "[e]very agency to consider the issue under the [predecessor Act] found statutory coverage for persons with asymptomatic HIV." 278 Yet despite being in agreement with these consistent agency determinations, the Court declined the invitation to defer under Chevron. ${ }^{279}$ Instead, the Court explained that it was unclear whether Chevron deference could be accorded to an agency's

\footnotetext{
272 See Massachusetts Board of Retirement v Murgia, 427 US 307, 312-14 (1976).

${ }_{273}$ See Rehabilitation Act of 1973 , Pub L No 93-112, 87 Stat 355 , codified at 29 USC $\S 701$ et seq.

${ }^{274}$ City of Cleburne, Tex v Cleburne Living Center, Inc, 473 US 432, 442-47 (1985).

275 See 42 USC $\$ 12101(\mathrm{a})(1)$.

276524 US 624 (1998).

277 See id at 628 . The ADA defines disability as "a physical or mental impairment that substantially limits one or more of the major life activities of such individual." 42 USC $\$ 12102(2)$. This was virtually the same as the definition that Congress gave to "handicapped individual" under the earlier Rehabilitation Act of 1973. Rehabilitation Act of 1973, Pub L 93-112, codified at 29 USCA $\$ \S 701$ et seq.

278 Bragdon, 524 US at 642.

279 See id.
} 
interpretation when Congress did not delegate authority to a single agency. 280 Since it was unclear whether Chevron deference was appropriate, the Court proceeded to simply treat the agency views as guidance under Skidmore for its independent judgment that the ADA protected persons infected with HIV. ${ }^{281}$

In a case decided the next year, Sutton v United Air Lines, Inc, ${ }^{282}$ the Court again engaged in Chevron avoidance, this time to override an agency interpretation. ${ }^{283}$ Sutton addressed the question of whether individuals with extremely poor vision were disabled under the ADA and therefore entitled to protection against employment discrimination. ${ }^{284}$ In the case, the Court avoided giving Chevron deference to EEOC legislative rules and interpretive guidelines construing the Act to protect these persons. ${ }^{285}$ The Court justified Chevron avoidance by explaining that "disability" was in the definitional section of the statute for which Congress gave no agency the authority to interpret. ${ }^{286}$ But, as Justice Breyer argued in dissent, the term "disability" also appeared in the employment title, for which Congress clearly delegated interpretive authority to the EEOC. ${ }^{287}$ The Sutton majority nonetheless proceeded to independently determine whether the class of persons with extremely poor vision fit within the statute's definition of disability. ${ }^{288}$

In a third case, General Dynamic Land Systems, Inc $v$ Cline, ${ }^{289}$ the Court again avoided applying Chevron deference on the issue of a class's entitlement to statutory protection. Cline involved the question of whether younger workers were entitled to legal protections under the ADEA when employers favored older workers. ${ }^{290}$ The Court explained it did not need to decide whether to apply Chevron or Skidmore deference to the EEOC's legislative rule interpreting the Act because the language and

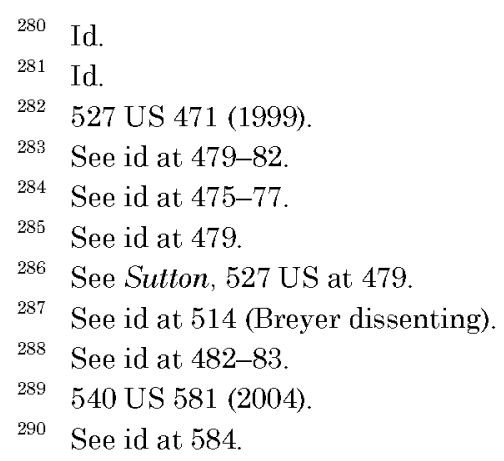


structure of the statute indicated a clear congressional intent solely to "protect the older from arbitrary favor for the younger." 291 The majority's finding of statutory clarity in statutory text that seemed quite ambiguous was questionable, but that is not what made the case unusual. Instead, it was the decision to interpret the statute outside of the Chevron framework. When the justices find clarity in ambiguous text they usually do so at Chevron step one, which asks whether the intent of Congress was clear. ${ }^{292}$ But in Cline, the court used statutory clarity as an excuse to avoid making a choice about the applicable deference framework. The Court has very rarely done this in other cases. ${ }^{293}$ Even the justices in the dissent who agreed with the agency's interpretation of the statute refused to apply Chevron. ${ }^{294}$ Only Justice Scalia, writing alone, argued that the Court should have applied Chevron deference and deferred to the agency interpretation. ${ }^{295}$

These Chevron avoidance cases are especially notable because the Court did not always avoid giving Chevron deference to agencies' formal interpretations of the ADEA and ADA. As it did with respect to the Civil Rights Act and the VRA, the Court treated agency interpretations involving nonconstitutional matters very differently. For example, the Court applied heightened deference without hesitation to agencies' statutory determination about the administrative procedures that a claimant was required to follow under the ADEA, ${ }^{296}$ the scope of exemptions for discriminatory bona fide employee benefit plans under the ADEA, ${ }^{297}$ and the affirmative defenses

291 Id at 600 .

292 This form of textual review has been characterized as hypertextualism-the process of finding "linguistic precision where it does not exist". See Richard J. Pierce Jr, The Supreme Court's New Hypertextualism: An Invitation to Cacophony and Incoherence in the Administrative State, 95 Colum L Rev 749, 752 (1995).

${ }^{293}$ See Sunstein, $92 \mathrm{Va} \mathrm{L} \mathrm{Rev} \mathrm{at} \mathrm{221-22} \mathrm{(cited} \mathrm{in} \mathrm{note} \mathrm{37)} \mathrm{(describing} \mathrm{a} \mathrm{step-zero}$ process in which the Court must ascertain whether the agency interpretation has the force of law to determine whether Skidmore or Chevron applies).

294 Cline, 540 US at 605 (Thomas dissenting) (agreeing with the majority that "we need not address" whether Chevron deference would apply to the agency regulation in the case).

295 See id at 601 (Scalia dissenting) (arguing that the statute is ambiguous and that the agency's interpretation was "neither foreclosed by the statute nor unreasonable").

296 See Oscar Mayer, 441 US at 761.

297 See Public Employees Retirement System of Ohio v Betts, 492 US 158, 171 (1989). 
available to the employer under the ADA. ${ }^{298}$ In each of these cases, the Court could have avoided Chevron deference using the same methods as it had in Bragdon, Sutton, and Cline, but the Court instead applied Chevron. The contrast between these two sets of cases provides further support for the argument that the deference dichotomy is, at best, an incomplete explanation for the Court's deference choices in the civil rights domain.

These ADEA and ADA cases also further undermine the argument that ideology drives deference choices. With the exception of Justice Scalia in Cline and Justice Breyer in Sutton, all of the justices engaged in Chevron avoidance even when the agency's interpretations accorded with their view of the meaning of the statute. Thus, these cases suggest that the Court's choice of deference doctrine is not merely about ideology. Finally, the pattern of cases does not fit the explanation that the statute's complexity or judicial views about the agency's competency influenced deference choices. Again, the Court vacillated between applying heightened deference to some agency interpretations of the ADEA and ADA and minimal-to-no deference to others, which undercuts both the statute- and agency-specific accounts.

B. Why Judicial Resistance to Administrative Constitutionalism?

What is at stake when the Court chooses to apply a particular deference model? Explaining judicial resistance to administrative constitutionalism requires answering this question. When the Court applies heightened deference to an agency interpretation under "great deference," Chevron deference, or any similar framework, it essentially concedes to the agency the primary authority to interpret the statute. ${ }^{299}$ The Court sends the important message that it is the agency that exercises principal control over the meaning of the statute. The Court can, of course, still override these interpretations, but it

\footnotetext{
298 See Chevron, 536 US at 78-79.

299 See Lisa Schultz Bressman, How Mead Has Muddled Judicial Review of Agency Action, 58 Vand L Rev 1443, 1446 (2005) ("While Chevron deference means that an agency, not a court, exercises interpretive control, Skidmore deference means just the opposite."); Diver, $133 \mathrm{U} \mathrm{Pa} \mathrm{L} \mathrm{Rev} \mathrm{at} 568$ (cited in note 25) ("The choice between deferential and independent review is really about the allocation of interpretive responsibility between administrative agencies and courts.").
} 
must overcome the burden of showing that the agency's interpretation is contrary to clear congressional intent or is unreasonable. As empirical studies of deference doctrine reveal, such standards still leave room for judicial manipulation to secure preferred outcomes. ${ }^{300}$ But the message of agency control over the meaning of the statute is significant independent of whether it increases the likelihood that the agency interpretation will be accepted. Deference relegates courts to secondary actor status in statutory interpretation. It makes the agency the focal point of contestation and deliberation about statutory meaning. When agencies are the focal point, individuals and interest groups are likely to focus greater attention on the agency's actions, participating in the process of decision-making when the opportunity arises and otherwise providing information about factual context and interests implicated by the agency decision. In addition, the legislative and executive branches have greater incentives to oversee these agency actions.

In contrast, when the Court subjects agency interpretations to minimal deference under Skidmore, or other similar frameworks, or provides no deference at all, it is asserting judicial primacy over the meaning of the statute. The Court then has the discretion to give the agency interpretation whatever persuasive value the Court chooses to assign to it. Using this discretion, the Court may, as some empirical studies suggest, end up using this authority to overturn the same proportion of agency interpretations as it does under the heightened deference framework. ${ }^{301}$ But even so, the key consequence is that the Court, not the agency, emerges as the central focal point of contestation and deliberation about the meaning of the statute. Statutory interpretive questions are resolved in the courts, not though engagement between individuals, interest groups, and agencies with some oversight from the legislative and executive branches. The judicial choice about deference doctrine is thus a choice about who controls the meaning of statutes, and particularly who is involved in statutory interpretation, with implications that go beyond any impact on particular case outcomes. ${ }^{302}$

\footnotetext{
300 See Part I.C.

301 See Part I.C.

302 The question that this also raises is why the Court would ever give up control
} 
Further, when agencies interpret statutes in ways that engage ongoing constitutional controversies in the courts, their actions have direct implications for judicial supremacy. This judicially constructed principle, which asserts that courts are the final and exclusive interpreter of the Constitution, has been central to the Supreme Court's institutional identity since the 1950 s when the Court famously equated its interpretation of the Constitution with the Constitution itself. ${ }^{303}$ The Court's assertion of this supreme authority over constitutional meaning in recent cases narrowing congressional authority to enforce the Fourteenth Amendment has been well chronicled. ${ }^{304}$ In a series of cases in the $1990 \mathrm{~s}$, the Court made clear that Congress lacked the authority to define the substance of equal protection or due process. ${ }^{305}$ Such authority belonged only to the Court. Judicial

over the meaning of a statute. The Administrative Procedure Act certainly did not mandate that courts relinquish control to agencies over the meaning of statutes. In fact, the language of the judicial review provision of the statute suggests the opposite to be the case-that Congress intended for courts to exercise control over the meaning of agency-administered statutes in all contexts. See 5 USC $\$ 706$ ("To the extent necessary to decision and when presented, the reviewing court shall decide all relevant questions of law, interpret constitutional and statutory provisions, and determine the meaning or applicability of the terms of an agency action."). The Court, however, is resource constrained and has to make choices about when and how it wants to exercise its authority. To review as a de novo matter all statutory interpretation questions addressed by agencies would likely overwhelm the judicial system. See, for example, Judith Resnik, Migrating, Morphing, and Vanishing: The Empirical and Normative Puzzles of Declining Trial Rates in Courts, $1 \mathrm{~J}$ Empirical Legal Stud 783, 798-801 (2004) (comparing the number of federal and agency adjudications in 2001 and finding that federal judges "closed just under 60,000 'adversary proceedings," while agencies closed an estimated 720,000 proceedings)

303 See Cooper v Aaron, 358 US 1, 18 (1958).

304 See, for example, Robert C. Post and Reva B. Siegel, Protecting the Constitution from the People: Juricentric Restrictions on Section Five Power, 78 Ind L J 1, 17-41 (2003).

305 Section 5 of the Fourteenth Amendment gives Congress the authority to enforce the Equal Protection Clause with appropriate legislation. See US Const Amend XIV, $§ 5$. The Court in a series of cases has narrowed congressional enforcement authority to remedying constitutional violations found by the Court. See City of Boerne v Flores, 521 US 507, 519 (1997) (limiting congressional authority to remedying or preventing unconstitutional action and prohibiting Congress from substantively changing the meaning of the Constitution). The Court has invalidated provisions as exceeding congressional enforcement authority that have given the aged and the disabled the right to sue states for damages under statutes protecting these groups from discrimination. See Board of Trustees of University of Alabama v Garrett, 531 US 356, 368-74 (2001) (finding that the enactment of the employment title of the ADA exceeded congressional authority under Section 5 of the Fourteenth Amendment, therefore depriving private individuals a right to sue states under the statute); Kimel $v$ Florida Board of Regents, 528 US 62, 80-91 (2000) (concluding that the ADEA exceeded congressional authority under Section 5 of the Fourteenth Amendment, therefore depriving private individuals a right to sue states under the statute). In each case in which the Court has invalidated a 
resistance to administrative constitutionalism emerges as another means by which the Court asserts judicial supremacyyet it has thus far been overlooked. Through resistance to administrative constitutionalism, the Court has denied to agencies the authority to both independently define the substance of the Fourteenth and Fifteenth Amendments and determine how those amendments should apply in particular contexts. Rather, through denial of deference, the Court has retained supreme authority over constitutional meaning.

C. Implications of Judicial Resistance to Administrative Constitutionalism

What does judicial resistance to administrative constitutionalism mean for the future of civil rights statutes? Maggie Lemos has demonstrated empirically that Congress's choice of where to delegate authority - to courts or agencieshas been a central determinant of Title VII's scope. ${ }^{306}$ If one believes in the rhetoric of the deference dichotomy, the choice to delegate belongs to Congress - all Congress needs to do is give agencies the authority to promulgate rules with the force of law, and then the Court will defer pursuant to Chevron and Mead. ${ }^{307}$ Implicitly, then, Congress can control the scope of Title VII through its choice of delegate, even when it does not choose to specify that scope directly.

But in the civil rights domain it appears that the choice of delegate does not entirely belong to Congress. When agencies promulgate rules on non-constitutional matters, the Court will usually respect Congress's choice of delegate. But when the statutory question implicates a constitutional controversy, the Court ignores or overrides the congressional choice and gives itself authority over the meaning of the statute irrespective of the form of agency interpretation or the demands of the relevant deference framework. When Constitution-laden statutory ambiguities arise, the meaning of the civil rights statutes will be strongly influenced by the Court's constitutional jurisprudence.

statute as exceeding congressional authority under Section 5 of the Fourteenth Amendment, it has conceded that Congress maintains authority to adopt statutes pursuant to its Commerce Clause power.

${ }^{306}$ Lemos, Vand L Rev at 389 (cited in note 102).

307 See White, 99 Mich L Rev at 582-83 (cited in note 102). 
While Congress has, at times, reasserted control over the meaning of civil rights statutes through amendments, the infrequency of those amendments demonstrates Congress's constraints in playing an active role in the evolution of statutes. ${ }^{308}$ What we can therefore expect in the future is that the agencies will be given authority to define more technical statutory provisions, such as unique procedural defenses and burdens of proof in contexts of statutory ambiguity. But since many of the central substantive components of these statutes implicate constitutional controversies, the scope of these statutes will likely continue to reflect judicial constructions of the Constitution.

\section{CONCLUSION}

The Court has defined a role for itself as the principal interpreter of the Constitution. Due to the limits of its institutional power and legitimacy, the Court has not always been able to exercise supreme authority over the meaning of all aspects of the Constitution. ${ }^{309}$ But since the mid-twentieth century, the Court's authority to define the extent of individual rights protected under the Constitution has grown to the point where it is now virtually unchallenged by Congress, the President, or the People. ${ }^{310}$ The Court's claim of supreme constitutional authority to define what rights the Constitution protects has led it to limit congressional authority to enforce alternative constitutional constructions.

308 See Bertrall L. Ross II, Against Constitutional Mainstreaming, 78 U Chi L Rev 1203, 1228-29 (2011) (arguing statutory overrides are exceedingly rare). There have only been three significant legislative overrides of judicial interpretations of civil rights statute in the past fifty years. See Fannie Lou Hamer, Rosa Parks, and Coretta Scott King Voting Rights Act Reauthorization and Amendments Act of 2006, Pub L No 109246, 120 Stat 577, overriding Reno v Bossier Parish School Board, 528 US 320 (2000); Civil Rights Act of 1991, Pub L No 102-166, 105 Stat 1071 (1991), codified at 42 USC $\$ 2000 \mathrm{e}-2(\mathrm{k})$ (overriding a series of Supreme Court interpretations of the Civil Rights Act of 1964); Pregnancy Discrimination Act of 1978, Pub L No 95-555, 92 Stat 2076 (1978), codified at 42 USC $\$ 2000 \mathrm{e}(\mathrm{k})$, overriding Gilbert.

309 See Rachel E. Barkow, More Supreme Than Court? The Fall of the Political Question Doctrine and the Rise of Judicial Supremacy, 102 Colum L Rev 237, 240 (2002) ("Underlying the political question doctrine ... is the recognition that the political branches possess institutional characteristics that make them superior to the judiciary in deciding certain constitutional questions.").

310 Larry Kramer, The People Themselves: Popular Constitutionalism and Popular Review 208 (Oxford 2004) (describing judicial supremacy with respect to the Constitution as the prevailing conventional wisdom). 
But even before the Court began to directly constrain Congress's constitutional authority, the Court actively resisted the authority of agencies to elaborate constitutional meaning. The primary tool for this resistance to administrative constitutionalism, at least in the civil rights domain, has been through the choice of deference doctrine. In the civil rights domain, the Court has consistently denied heightened deference to agency interpretations implicating ongoing constitutional controversies even when such denial conflicts with the deference dichotomy or precedent. The message the Court sends with these choices is that courts and not agencies represent the proper forum for public contestation and deliberation over constitutional values. As a result of such resistance to administrative constitutionalism, civil rights statutes often hew to the Court's construction of the Constitution-rather than to the interpretations of the officials charged with implementing civil rights. Depending on one's ideological orientation and the future composition of the Court, that may be a good or bad thing, but it will not necessarily represent the intent of Congress. ${ }^{311}$

${ }^{311}$ While I lack the space to consider the normative merits of administrative constitutionalism here, in a work-in-progress, I address the case for administrative constitutionalism head-on. See Bertrall L. Ross II, Embracing Administrative Constitutionalism, $95 \mathrm{BU}$ L Rev __ (forthcoming 2015). 
